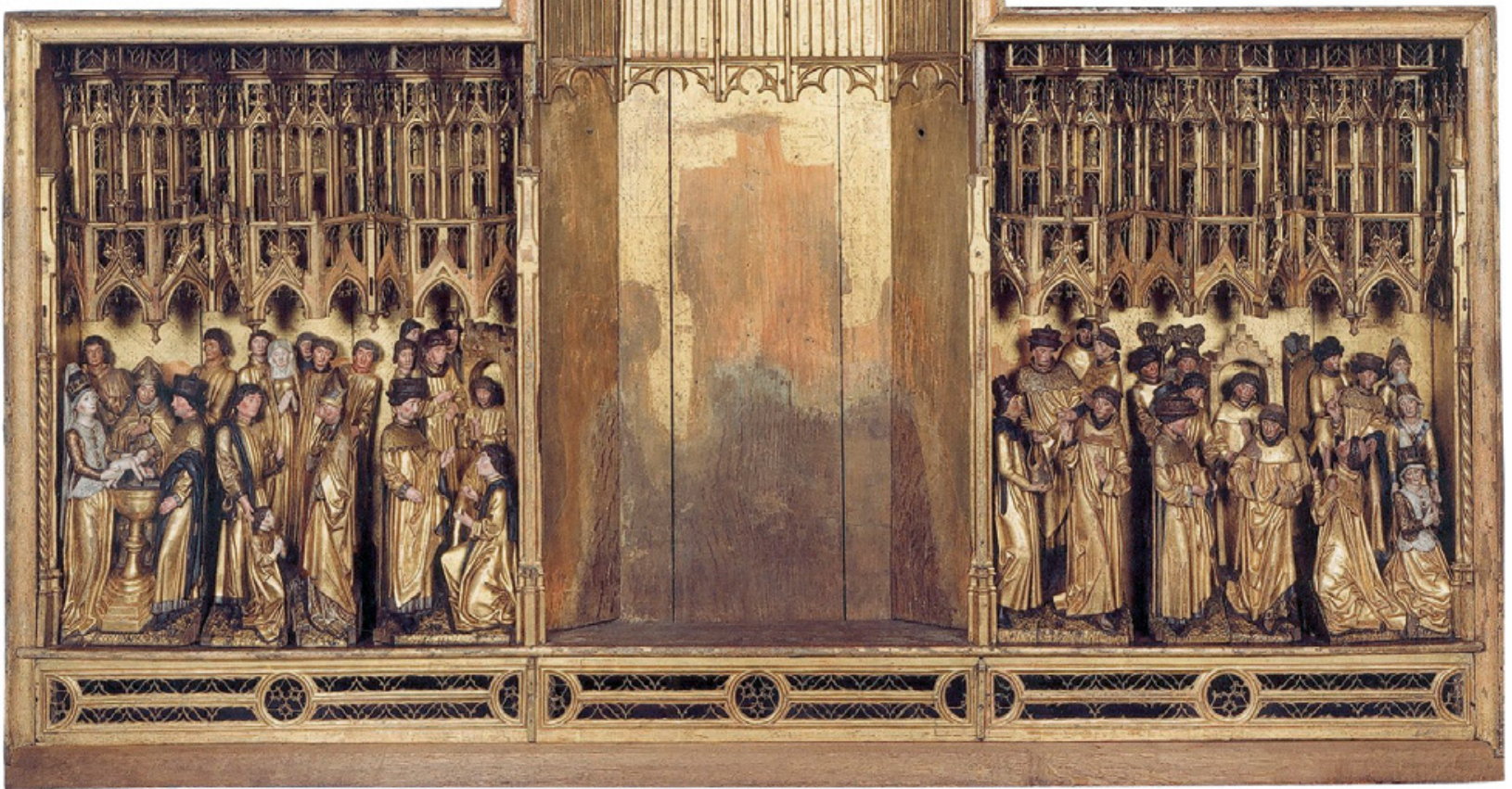




\section{The Cult of Saint Leonard at Zoutleeuw}

\section{Saint Leonard's Altarpiece}

In July 1476 , the churchwardens of Zoutleeuw gathered in a tavern to discuss commissioning an altarpiece dedicated to Saint Leonard. After their meeting, they placed an order in Brussels, and the work was finished in March 1478. The churchwardens again travelled to Brussels to settle the payment, and the retable was shipped to Zoutleeuw via Mechelen. ${ }^{1}$ The subject and the style, as well as the presence of Brussels quality marks on both the sculpture and the case of the oldest retable preserved in the Zoutleeuw church today (fig. 8), confirm that it is the very same one that was commissioned in $1476 .^{2}$

Saint Leonard, the Christian hero of the altarpiece, lived in Merovingian France around the year 500. His hagiography identifies his parents as courtiers to King Clovis and states that he had been baptized and instructed in Christian faith by Saint Remigius, archbishop of Reims. Leonard quickly won Clovis' goodwill, and was granted many favors by him. Not only was he allowed to free the prisoners he visited, he was also offered a bishopric. However, preferring solitude and prayer he refused the honor and instead went to live in a forest near Limoges, where he preached and worked miracles. One of these wonders involved the pregnant queen, who had joined her husband on a hunting party in the woods and was suddenly seized by labor pains. Leonard prayed on her behalf for safe delivery. His efforts were successful, and in gratitude Clovis had the monastery of Noblac built for him, where his miracles attracted pilgrims from far and wide, and where he finally died on 6 November 559 . His tomb (now Saint-Léonard-de-Noblat) became the primary center of pilgrimage for his devotion, but he would eventually be venerated all over western Europe, where he 'became a cure for the weak [and] untied the chains of prisoners'. 3

This is the story that is depicted in the altarpiece, where his life unfolds in six distinct sculptural groups under stately gothic canopies. The groups on the left side depict Leonard's pre-monastic life (fig. 9). The first group shows Clovis and his wife attending the baptism of Leonard by archbishop Remigius, to whom Leonard's
FIGURE 8

Anonymous (Brussels), Altarpiece depicting the life of Saint Leonard, 1476-1478, Zoutleeuw, church of Saint Leonard

(C) KIK-IRPA, BRUSSELS

(C) RUBEN SUYKERBUYK, 2020 | DOI:10.1163/9789004433106_003

This is an open access chapter distributed under the terms of the CC BY-NC-ND 4.o license. 


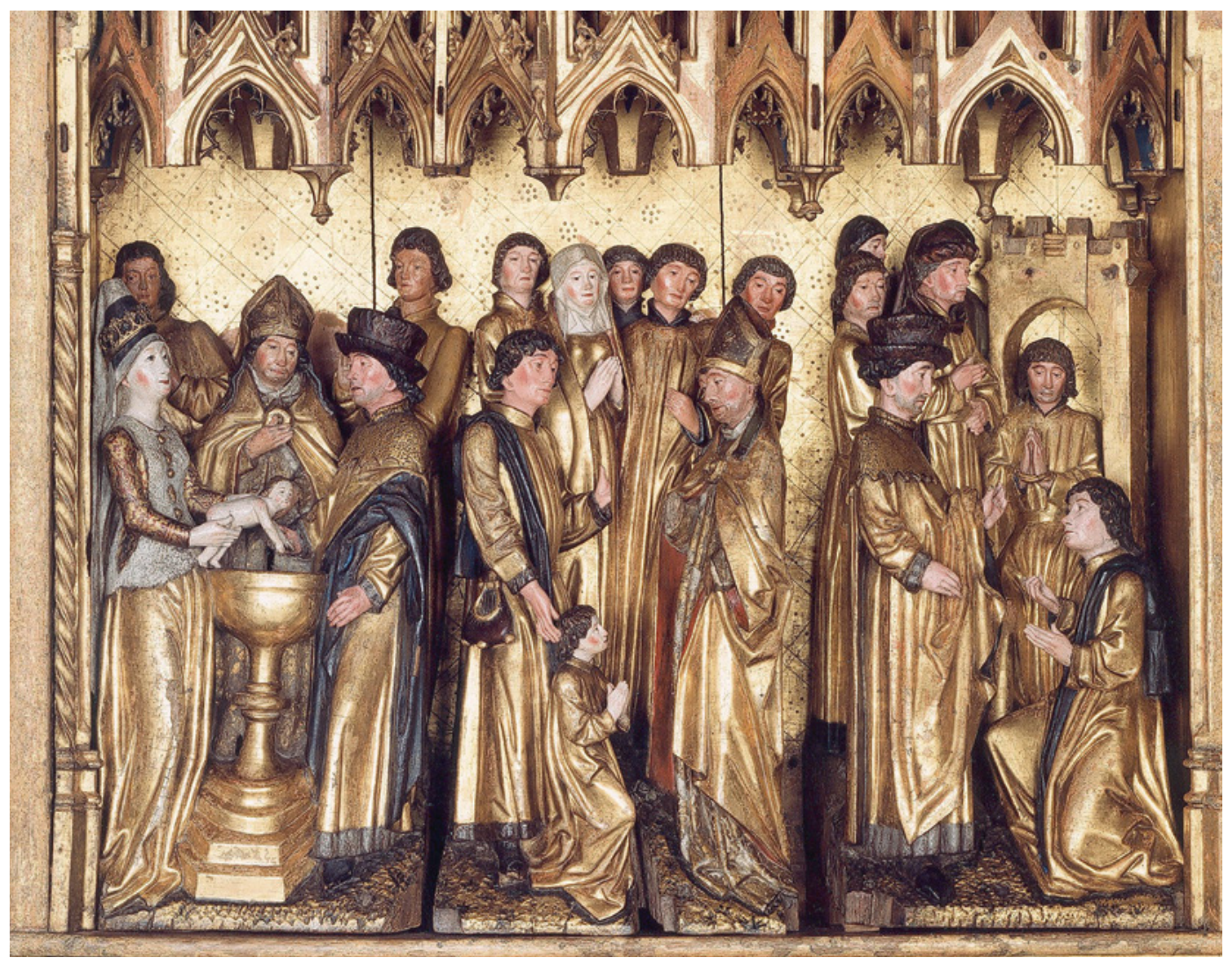

FIGURE 9

Detail of Fig. 8, left side

(C) KIK-IRPA, BRUSSELS parents present him for instruction in the next group. Leonard is subsequently shown at an older age, imploring the king to liberate the chained prisoner standing behind him. The monastic life of the saint begins on the right side of the altarpiece (fig. 10). First, he is shown refusing the episcopal miter proposed to him by Clovis, who instead offers him the monastery in the woods in the next group. Finally, Leonard's miraculous intercession during the queen's delivery is shown.

The Zoutleeuw altarpiece bears all the characteristics typical of contemporary Brussels productions, most notably the inverted T-shape wherein figures are organized under architectural baldachins. To a certain extent, such carved altarpieces were variations on a standardized formula, and it has been argued that the role of patrons was limited as a result. ${ }^{4}$ No contract for the altarpiece has been preserved, but circumstantial evidence nevertheless indicates that the churchwardens closely supervised its visual program and outlook. While the accounts do not reveal the name of the sculptor, 


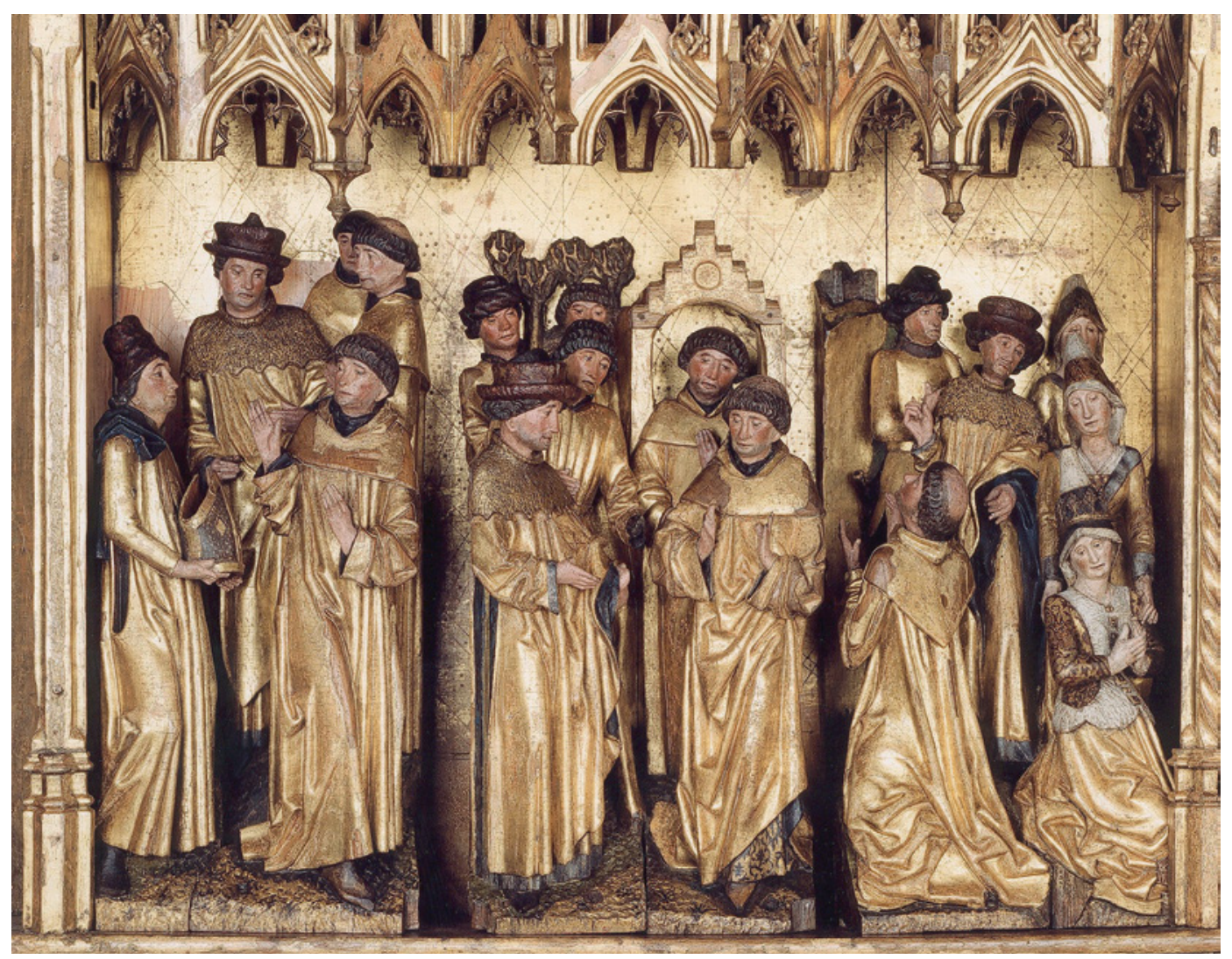

FIGURE 10

stylistic and technical analysis suggests that the same workshop also produced the prestigious passion altarpieces for the Italian merchant Claudio Villa and his wife Gentina Solaro (fig. 11), and Michel Detail of Fig. 8, right side (C) KIK-IRPA, BRUSSELS de Gauchy, councilor and chamberlain to Duke Philip the Good, and his wife Laurette de Jaucourt (fig. 12). ${ }^{5}$ This workshop clearly allowed its clients some say in the design, because De Villa's altarpiece has a form which is unusual for Brabantine norms, but typical for the artistic production in the patron's region of origin. ${ }^{6}$

Saint Leonard's altarpiece is atypical too, albeit from an iconographical point of view, as the absolute majority of the altarpieces carved in Brussels depict Christ's Passion or the life of the Virgin. ${ }^{7}$ The story of Saint Leonard's life of course circulated in hagiographical texts such as Jacobus de Voragine's Legenda Aurea, but the highly specific and unusual visual program must have been carefully chosen and defined beforehand. Indeed, the churchwardens commissioned the retable's design from a local artist: Arnold de Raet (act. 1447, d. 1484-1485) from Leuven, who had settled in Zoutleeuw and 


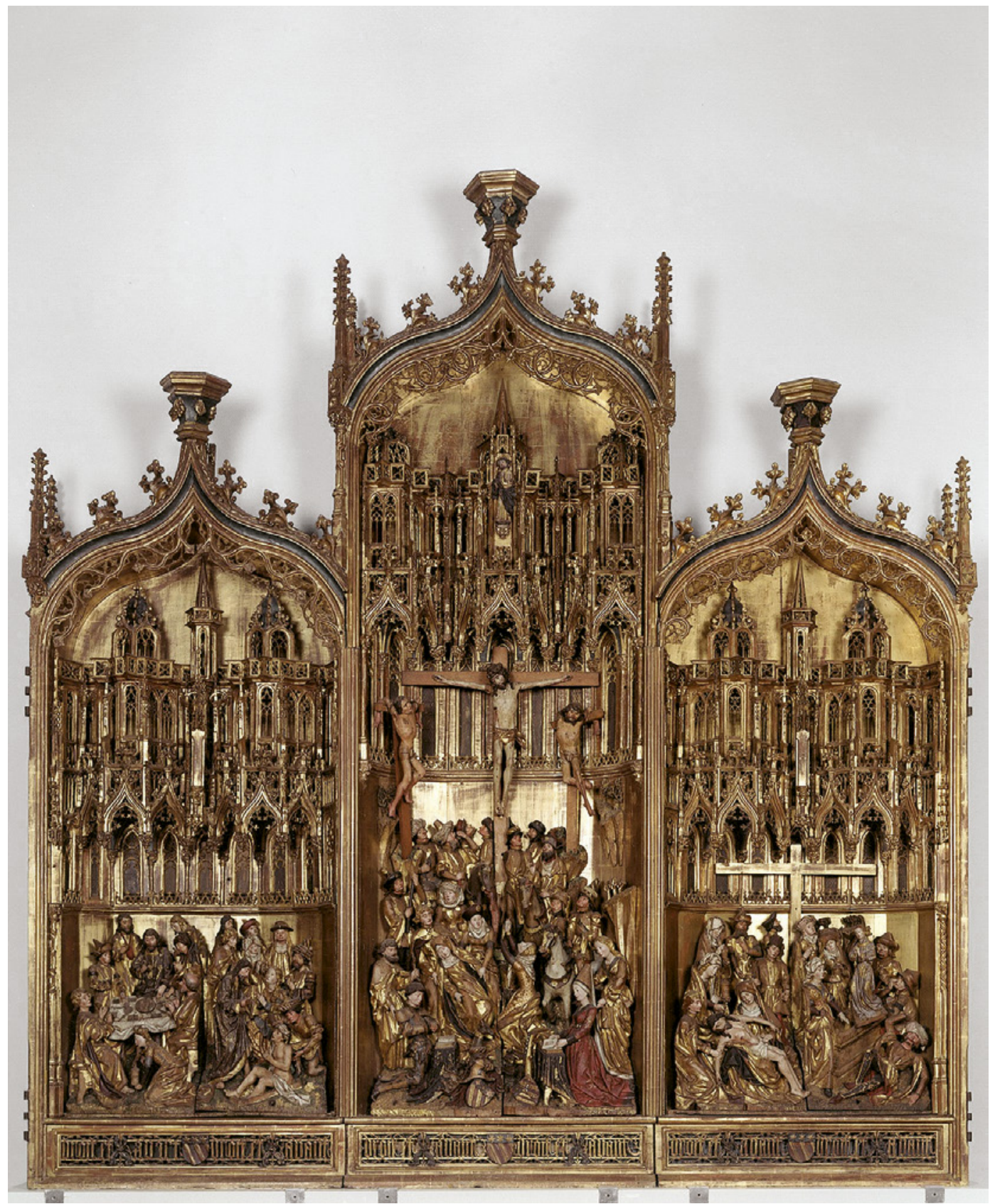

FIGURE 11 Anonymous (Brussels), Altarpiece of Claudio Villa and Gentina Solaro, c. 1470-1480, Brussels, Royal Museums of Art and History

(C) KIK-IRPA, BRUSSELS 


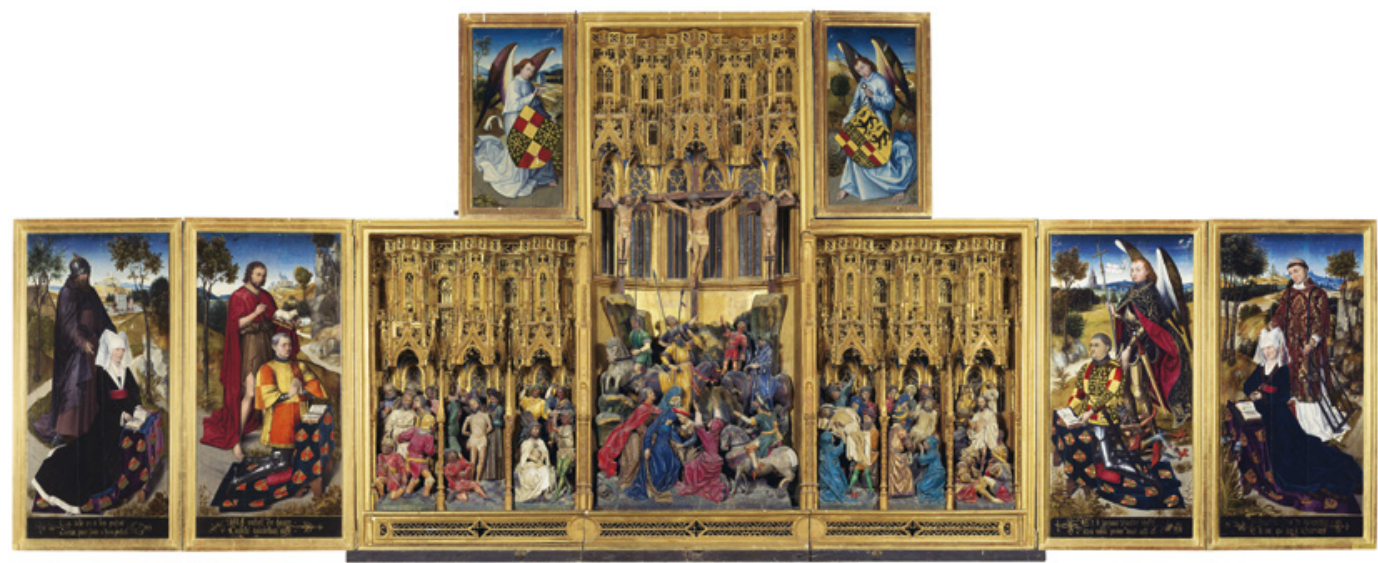

FIGURE 12

Anonymous (Brussels),

became the principal painter to the church between 1469 and $1482 .{ }^{8}$ Altarpiece of Michel de De Raet also accompanied the wardens to Brussels to place the Gauchy and Laurette de commission, suggesting that he figuratively translated the churchwarden's desires by setting out the retable's composition and iconographical program. ${ }^{9}$

The retable, however, has suffered significant alterations. Old Jaucourt, c. 1466, Ambierle, church of Saint Martin PHOTO: JOHAN GELEYNS - RO SCAN photographs not only reveal that the altarpiece was later combined with other, unrelated paintings and statues, they also show hinges at the top right, indicating the presence of wings which are now lost (fig. 13). Nevertheless, the available evidence suggests that the 1478 retable was initially wingless, in accordance with the dominant contemporary depiction of altarpieces (figs. 19, $38 \& 42$ ). ${ }^{10}$ The sculpted altarpiece forms a coherent iconographic ensemble, fully depicting Saint Leonard's hagiography from baptism to monastery. ${ }^{11}$ Wings would have disturbed the narrative continuity, from left to right, that was so typical for contemporary altarpieces. ${ }^{12}$ Lynn Jacobs has pointed out that such narrative disjunction was either the result of the cooperation of two entirely distinct workshops that did not attune their respective productions, or that the wings were a much later addition. ${ }^{13}$ Since Arnold de Raet is known to have provided an overall design for the altarpiece, the latter appears as the most reasonable option, and this was indeed a common practice. A case in point is the famous retable commissioned in 1475 by the Illustrious Brotherhood of Our Blessed Lady from 's-Hertogenbosch. The sculpted part was delivered by Adriaen van Wesel in 1477, but the painted outer wings were only commissioned from Hieronymus Bosch in 1488-1489. Polychromy of the sculpted parts would follow in 15081510 , and the inner wings would be painted later still, in $1522-1523 .{ }^{14}$ 


\section{FIGURE 13}

The Zoutleeuw Altarpiece depicting the life of Saint Leonard, state in 1900 , Brussels, Royal Institute for Cultural Heritage, cliché Boо 3676

(C) KIK-IRPA, BRUSSELS

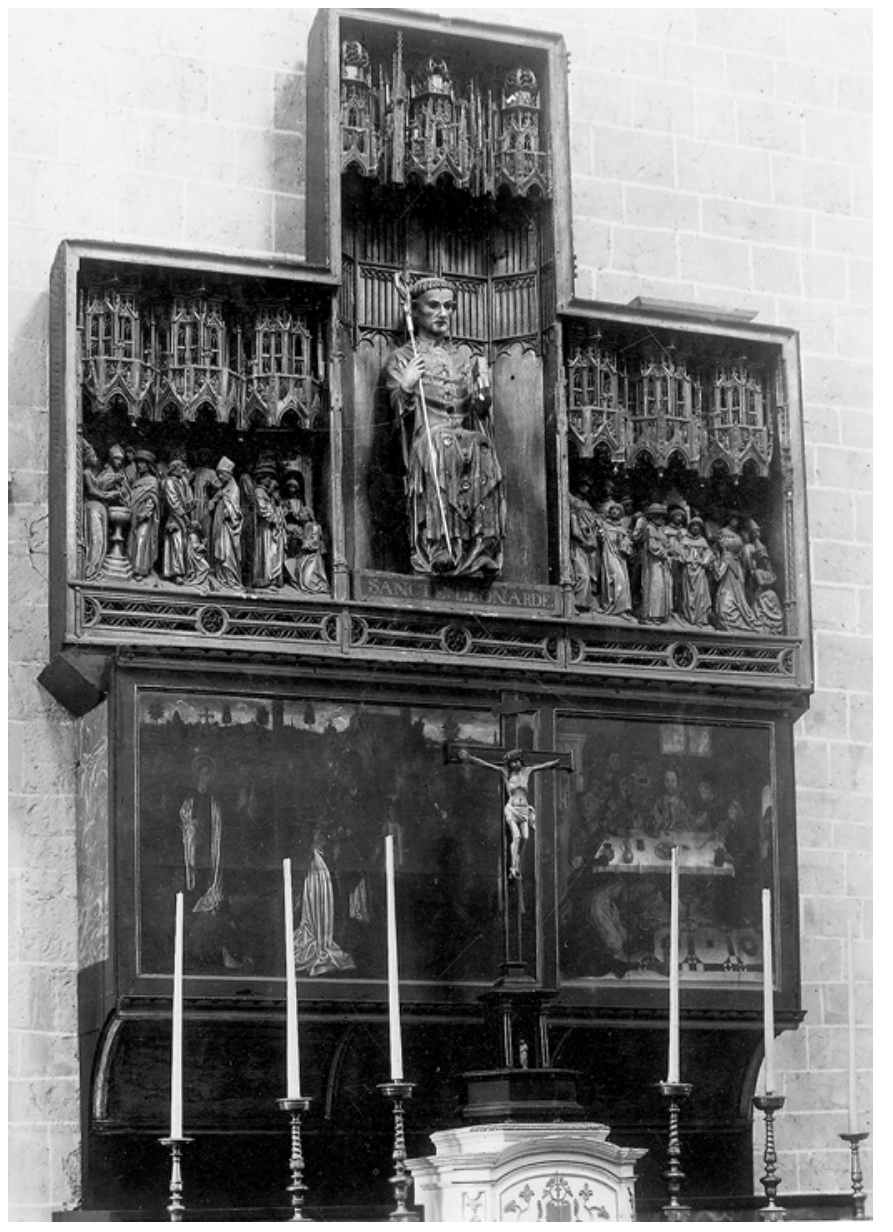

Finally, none of the documents pertaining to the Zoutleeuw commission refer to wings, and the total sum paid by the churchwardens (126 Rijnsgulden) conforms to prices of other wingless altarpieces. $^{15}$

The iconographic program of the initial design was thus limited to sculpted parts that were permanently visible, but these have been altered as well. From at least the nineteenth century onwards the central place of the altarpiece has mostly been occupied by an earlier statue of Saint Leonard (fig. 13). This has led to the hypothesis that the retable had actually been made to house that particular sculpture, which was soon rejected with good reason: the dimensions of statue and altarpiece do not correspond in any way, nor do the traces of the original gilding on the back wall of the case, which in fact suggest a lost sculptural group. ${ }^{16}$ Furthermore, as I will argue, the statue was originally installed in a separate tabernacle. The current 


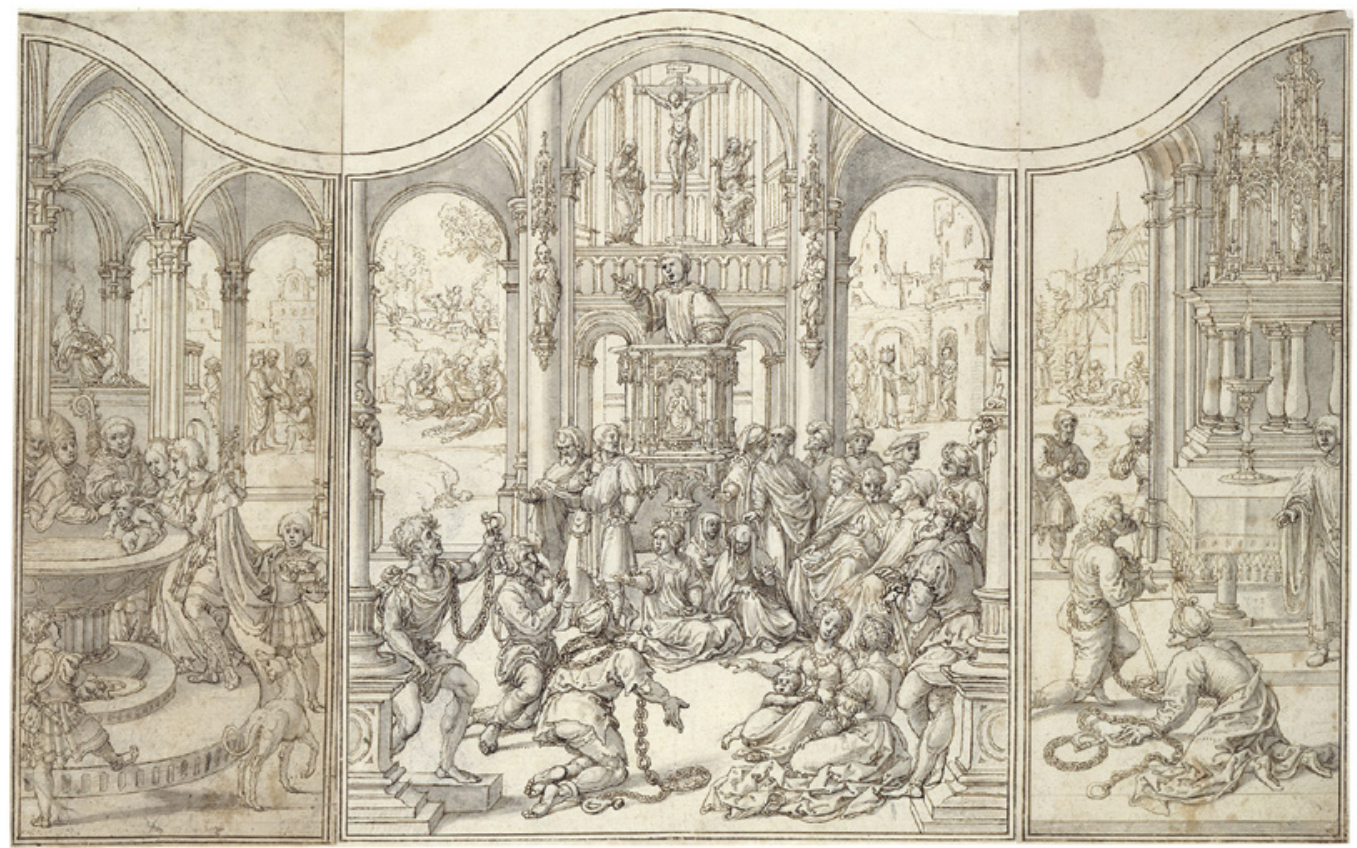

FIGURE 14

consensus therefore is that the original central scene of the altarpiece is lost.

The identification of its subject is pertinent nevertheless. Resulting from the formal emphasis created by the elevated top, the central spaces of carved retables were, as a rule, reserved for key moments in the depicted narrative. In many cases this was a Calvary group, and based on the evocative traces of the original gilding on the Zoutleeuw altarpiece it has been suggested that it similarly represented a crucifixion in the center. ${ }^{17}$ The presence of a crucifix on the altar was, after all, an established custom, and the centrality of the body of Christ in altarpieces indeed formed an apt visual backdrop to the priest's elevation of the host, the symbolic re-enactment of Christ's sacrifice during Mass. ${ }^{18}$ Calvary scenes were of course easily integrated into altarpieces devoted to either Christ or the Virgin, but in fact never were in pieces on other holy figures where they would - again - breach the narrative coherence. ${ }^{19}$ And while retables dedicated to Christian martyrs generally depicted their martyrdoms in the central niche as a parallel to Christ's passion, Saint Leonard was a confessor instead of a martyr as he had died in peace in his monastery. ${ }^{20}$

No other contemporary Netherlandish altarpiece dedicated to Saint Leonard has been preserved, but a later design by Jan Gossart from the 152 os provides valuable clues (fig. 14). ${ }^{21}$ On the wings and in
Jan Gossart, Design for a triptych with the life of Saint Leonard, c. 1520-1530, Berlin, Staatliche Museen, Kupferstichkabinett, $\mathrm{KdZ} 4647$ 
the background of the center panel, he depicted virtually the same subjects as the Zoutleeuw altarpiece. Clockwise starting from the lower left corner, the design shows the baptism of Saint Leonard, his instruction by Remigius, his refusal of the miter, the queen giving birth, the freeing of prisoners, the building of the monastery and the miracles that subsequently happened there. The latter is absent in Zoutleeuw, as is the central scene showing the saint in a church interior in the company of young mothers and prisoners. ${ }^{22}$ That very scene also conspicuously shows a crucifixion in the form of a triumphal cross on the rood loft behind the pulpit on which Saint Leonard is preaching - a clever solution allowing for the inclusion of the liturgical crucifix, while at the same time preserving the narrative unity. The same solution occurs in carved altarpieces too. The retable depicting the vita of Saint Renelde in Saintes, for instance, similarly sets the central scene in a church interior (fig. 15 ). ${ }^{23}$ It can therefore be assumed that the Zoutleeuw altarpiece centrally depicted Saint Leonard in a similar way: in a church interior, while preaching and working miracles, as was recounted in the Legenda Aurea.

The iconographical program thus foregrounded the saint's thaumaturgic character. By emphasizing two aspects from his hagiography that were the very reasons for his later cult, i.e. the freeing of prisoners and the comforting of pregnant women seeking a safe delivery, it presents him as a liberating saint capable of working miracles. ${ }^{24}$ As such, the significance of the altarpiece seems to extend beyond a strict liturgical framework. Although the early development of altarpieces was closely related to the liturgy, they were not essential to its celebration as they originated long after the rituals had taken on a fixed form. ${ }^{25}$ While the gilding and polychromy created strong visual parallels with genuine liturgical utensils and reliquaries, it provided retables with an aura of sacrality and liturgical importance that they did not have inherently. ${ }^{26}$ In recent years scholars have come to understand altarpieces as having been multifunctional objects between official prescriptions of the liturgy and people's individual devotional experiences, increasingly characterizing them as products of devotion. ${ }^{27}$

Reading altarpieces in devotional terms is indeed crucial, because the one in Zoutleeuw is in fact an early example of a veritable production wave of similar altarpieces in the period from grosso modo 1480 to 1520 , that were distributed throughout the Low Countries and elsewhere in Europe. ${ }^{28}$ Interestingly, comparably complex and equally materially splendid devotional objects, such as carved wooden prayer nuts, boomed during more or less the same period 


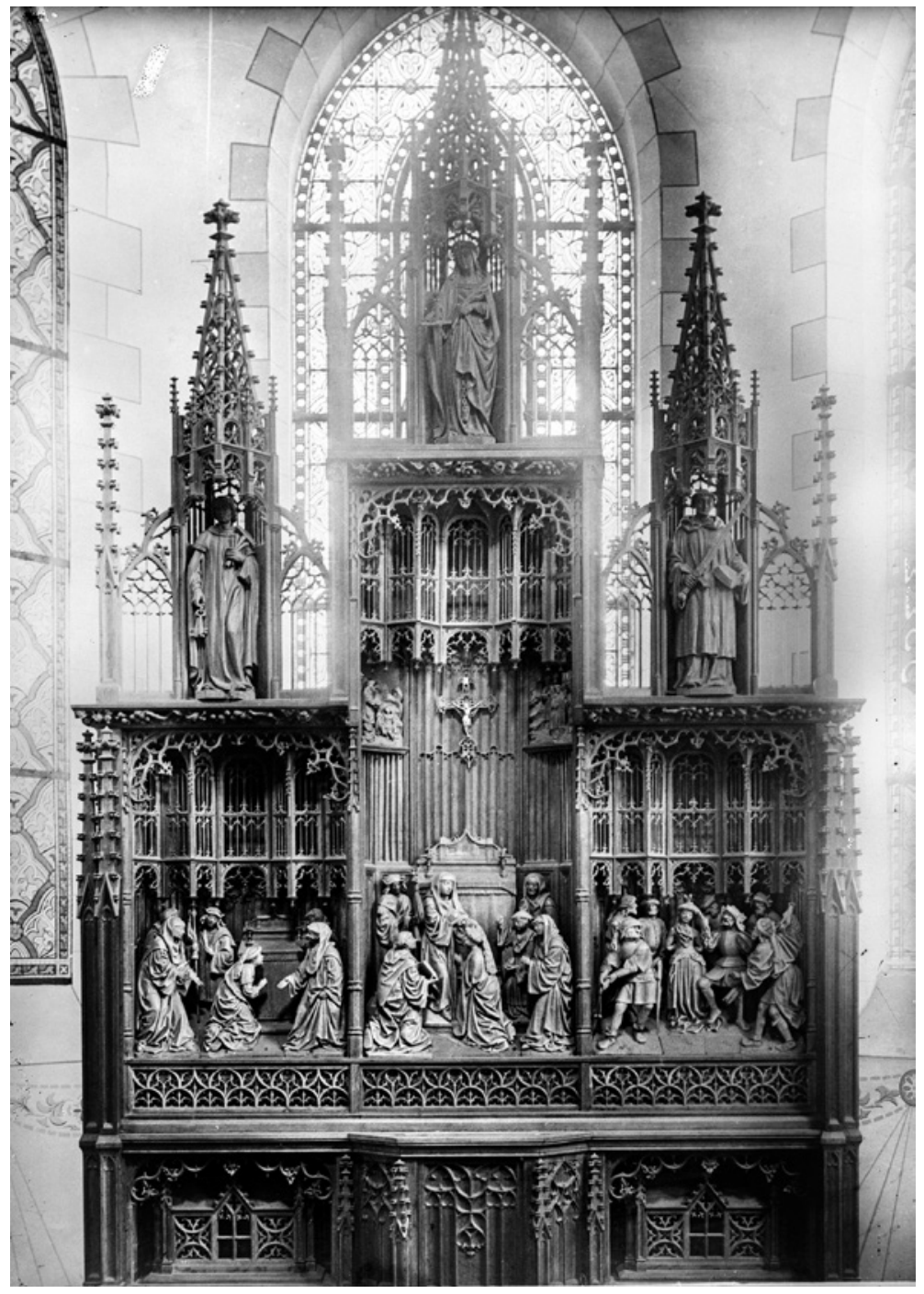

(c. 1500-1530). ${ }^{29}$ The broad popularity of such objects prompts the question of how they fit into contemporary lay devotion. A vast body of literature has recently emphasized the importance of increasingly spiritual ideals in late medieval piety, among others propagated by the Devotio Moderna movement. It is argued that laypeople, in imitation of the clergy, developed a growing criticism towards images and pursued an 'aniconic piety', i.e. the ideal of a devotion without images. ${ }^{30}$ Such an observation clearly is at odds with the material at hand and has rightly been termed paradoxical. After all, it is more logical to consider the material splendor of Brabantine altarpieces
FIGURE 15

Anonymous (Brussels), Altarpiece depicting the life of Saint Renelde, c. 1520, Saintes, church of Saint Renelde, state in 1917-1918, Brussels, Royal Institute for Cultural Heritage, cliché Aoog922

(C) KIK-IRPA, BRUSSELS 
as essentially an expression of contemporary piety, rather than being at odds with it. ${ }^{31}$ It is worthwhile to investigate the intended roles for altarpieces such as the one in Zoutleeuw in much the same way that Falkenburg has demonstrated that prayer nuts played a central role in devotional experience. ${ }^{32}$ In other words: in what devotional, liturgical and material context did the altarpiece function, and what prompted the churchwardens to commission a piece with such a particular iconographic focus at that precise moment?

\section{Protohistory of the Cult}

To answer this question it is necessary to trace the roots of Saint Leonard's cult in the early history of Zoutleeuw's religious landscape. In its earliest mention (1139), the Zoutleeuw parish is identified as the capital of a deanery within the Bishopric of Liège (decania Lewis). It testifies to the contemporary importance of the Zoutleeuw church and implies older origins, but this parish church was dedicated to Saint Sulpice, not to Saint Leonard. ${ }^{33}$ Only in 1231 would the seat of the parish be transferred from Saint Sulpice's church to the nearby chapel of Saint Leonard, 'for the greater convenience of the people. ${ }^{34}$ This transfer must be seen in relation to efforts on the part of the Counts of Leuven - and later the Dukes of Brabant to foster the development of the town of Zoutleeuw. In an attempt to secure and control the eastern frontier of their territory, they had given a number of privileges to stimulate the town's economic, political and social development from the early twelfth century onwards: the town was provided with walls, merchants were obliged to use its facilities in their trade over both water and land, an annual fair with Pentecost was instituted and the dukes even formally considered it as one of the seven 'free' or 'good cities' of the Duchy. ${ }^{35}$ The transfer of the parish from Saint Sulpice, which lay unprotected in the Zoutleeuw surroundings, to the centrally located chapel of Saint Leonard was an inherent part of these urban developments. ${ }^{36}$ It remains unclear when this initial chapel was erected, but it likely happened under the influence of the Bishops of Liège, in whose territories other sanctuaries to Saint Leonard were founded from the late eleventh century onwards. ${ }^{37}$ In sum, the capellam nunc ecclesiam Sancti Leonardi was likely the product of the ambitions of both the Dukes of Brabant and the Bishops of Liège, respectively attempting to maintain worldly and ecclesiastical power. Indeed, the fact that 


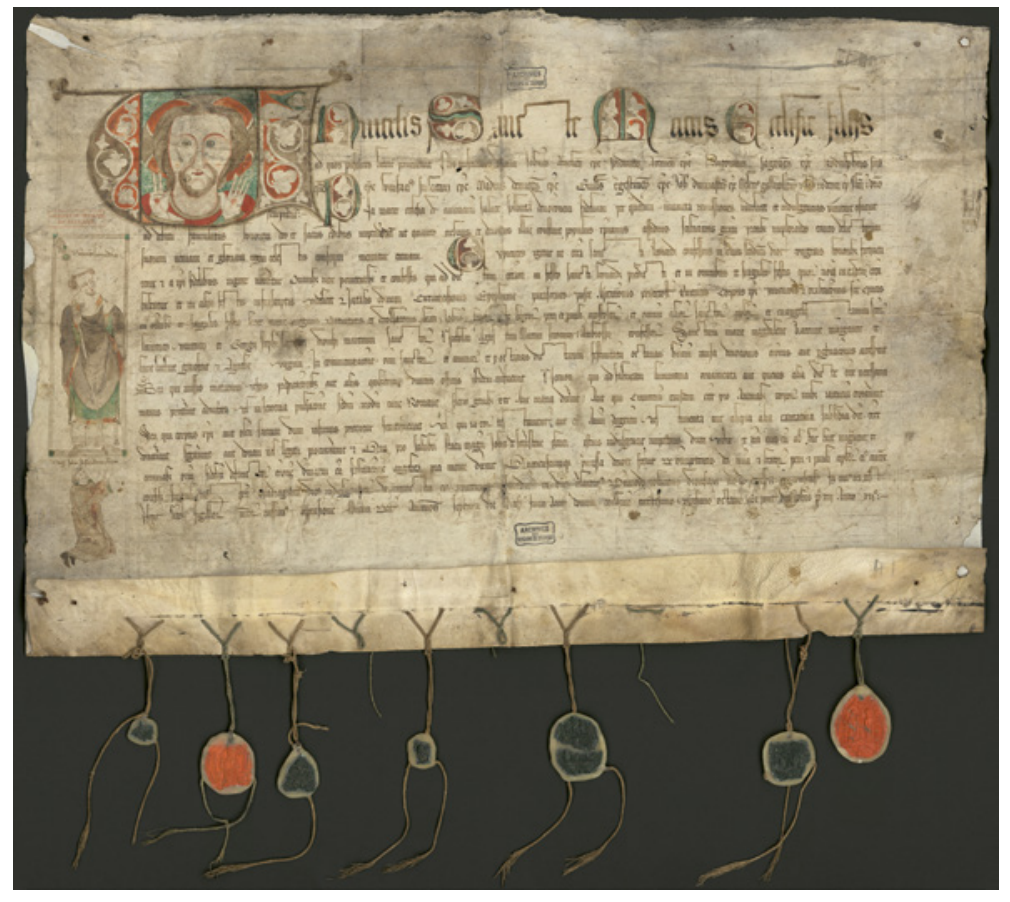

Saint Leonard's right of patronage was shared by the Liège chapter of Saint Denis and the Brabantine abbey of Vlierbeek - founded by Count Godfrey I of Leuven - suggests a compromise between the two powers. ${ }^{38}$

The chapel's elevation to parish church in 1231 prompted a series of building campaigns to adapt the sanctuary to accommodate the growing number of parishioners. The church was probably built around the former chapel before destroying it, as was a common practice at many gothic construction sites. Architectural analysis indicates that work started with the choir in the middle of the thirteenth century, to be followed by the northern transept and the same side of the nave with its tower later in that century. The southern side was built only in the early fourteenth century, seemingly to be concluded with the transept (fig. 4). ${ }^{39}$ The founding of the collegiate chapter of nine canons in 1308 - extended to eleven by the middle of the century - would provide an extra impetus to complete the construction. ${ }^{40}$

At this point, the church's patron saint was clearly not the object of a thriving cult, and certainly not one that was lucrative enough to finance the church's ongoing construction. In 1293 the town and the
FIGURE 16

Letter of indulgence awarded to the Zoutleeuw church of Saint Leonard, illuminated by the workshop of Galterius Alamannus, 1328, Leuven, Rijksarchief 


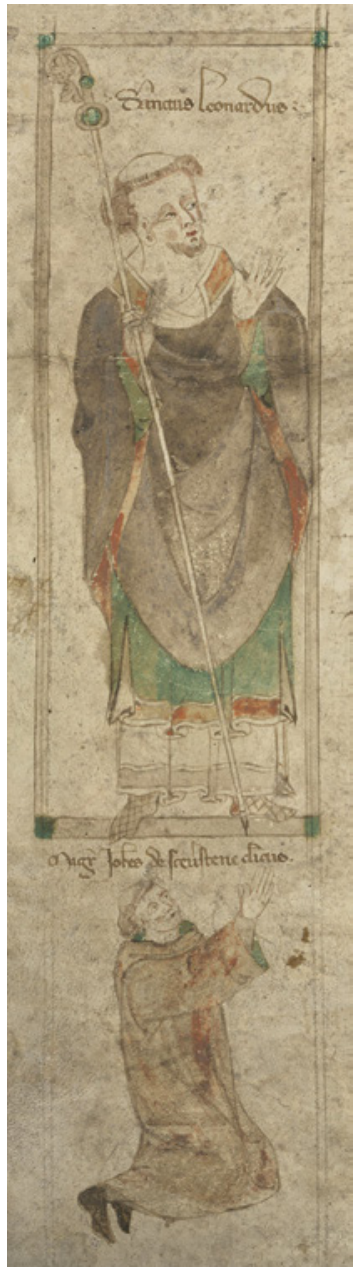

FIGURE 17

Detail of Fig. 16 clergy issued a letter of recommendation for collectors, stating that workers had started to build the most sumptuous church, but that the resources were lacking and one thus was compelled to beg alms of the faithful. ${ }^{41}$ The text significantly fails to mention any particular cult of relics or an image that was venerated in Zoutleeuw, and certainly does not use anything like it as an argument for fundraising, contrary to many other construction sites. A few years later, in 1328, a number of bishops residing in Avignon awarded an indulgence to the church at the personal request of magister Johannes de Sceverstene, a clergyman from Zoutleeuw. In established pilgrimage centers such documents included references to cult objects and their miracles, but the Zoutleeuw example does not include anything of the kind (fig. 16). ${ }^{42}$ It grants several days of indulgence to those who attended the liturgical services for a whole catalogue of saints, but Leonard is not especially emphasized among them and seems only mentioned perfunctorily for his role as patron saint. Apart from encouraging Christian believers to give money or offerings to the church, the indulgence in fact was essentially related to Sceverstene's personal spiritual welfare, since those who prayed for his salutary state would benefit from it. Sceverstene himself is depicted in the left margin of the document, represented in prayer before a figure of Saint Leonard (fig. 17). But this should not be taken as an indication of the presence of a cult, as it was a standardized illuminating procedure in Avignon to depict the patron saint of the requesting church. ${ }^{43}$

The acquisition of a statue representing Saint Leonard (fig. 18) was crucial for the developments in Zoutleeuw. The oak sculpture, just over a meter in height $(107 \mathrm{~cm})$, shows the confessor with tonsured head, identifying him as a monk. The figure is seated and holds a book in his left hand, while his right hand contains a tube-like fitting in which an abbatial staff can be placed. Certain aspects still refer to Romanesque sculpture traditions - most notably the inlaid gemstones decorating his priestly garments - but the figure's elongated pose points to the mid-fourteenth century. Recent technical investigations have confirmed these stylistic assessments, dating it to around $135^{\circ-1360.44}$ It is this statue that would eventually become the church's cult object and to which many a miracle would be attributed, thus providing a terminus post quem for Saint Leonard's cult in Zoutleeuw. But miraculous images were of course not commissioned as such. Beate Fricke has demonstrated that a distinction between cult statues and other religious images was alien to medieval terminology, which generically referred to sacra imago or imagines sanctorum. ${ }^{45}$ It would indeed seem that the Zoutleeuw 


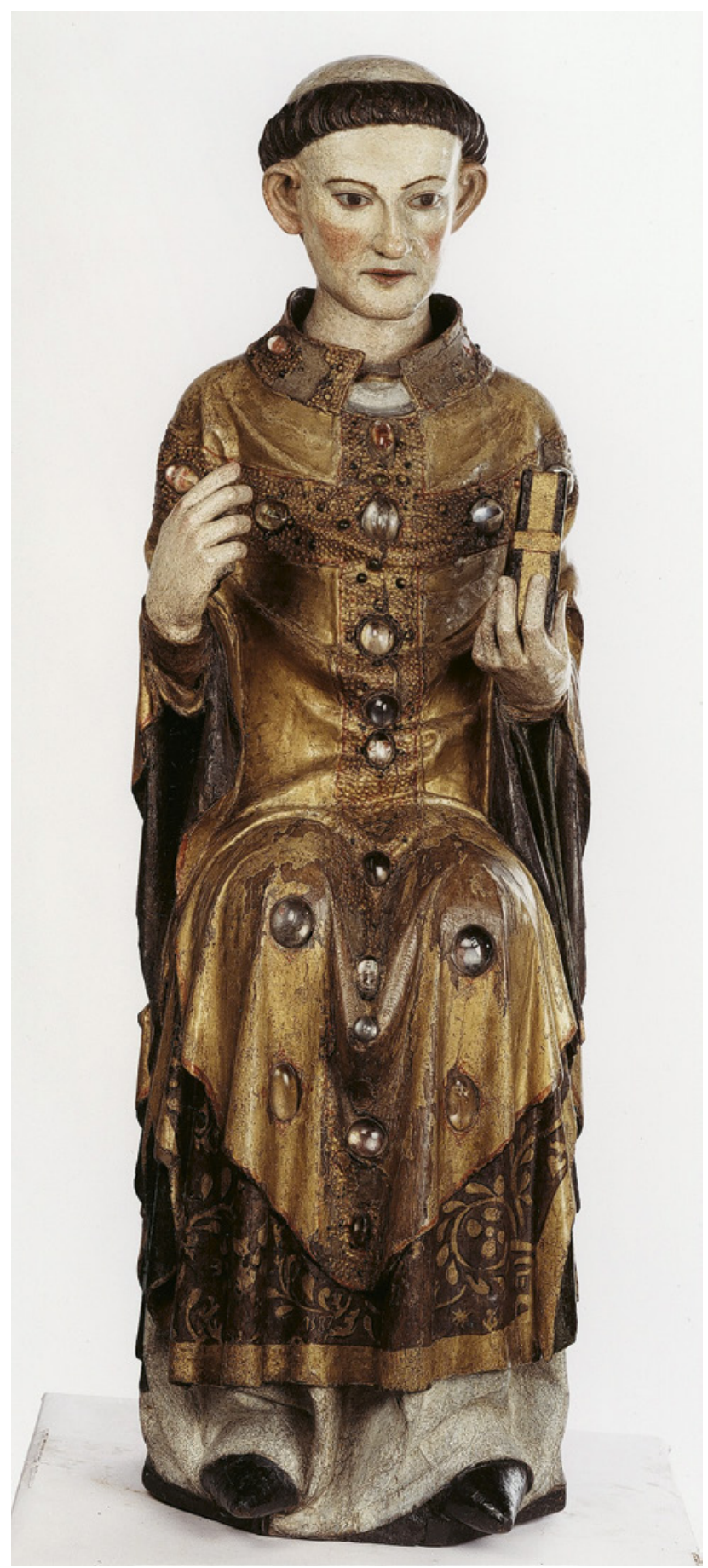

FIGURE 18 Anonymous, Saint Leonard, c. 1350-136o, Zoutleeuw, church of Saint Leonard

(C) KIK-IRPA, BRUSSELS 
statue initially served as a mere representation of the parish patron saint. Most cults actually developed around older artifacts, and miraculous images - referred to only in the sixteenth century as beelden van miraculen or miraculeuse beelden ${ }^{46}$ - had to earn their reputation. ${ }^{47}$ This functional evolution of images, so inherently related to the individual experiences that miracles were, cannot possibly be described in fixed chronological terms. Moreover, this ran parallel to another equally unpalpable transition; that of the liturgical veneration of a patron saint or the personal devotion to a saint in heaven into the actual cult of a material object at a specific location. The remainder of this chapter will trace and characterize this sinuous process.

It may be the case that early attempts to develop the church into a pilgrimage destination occurred quite soon after the statue's acquisition, but the evidence is unclear. In the 136os, Lewis - a locality possibly identifiable as Zoutleeuw - appears as destination in the Maastricht registers of judicial pilgrimages. This was a common form of correctional punishment in the medieval Low Countries, in which ecclesiastical or secular law courts obliged convicts to fulfill one or more pilgrimages to specified destinations. Starting in 1367 , the number of Maastricht convicts sent to Lewis reached a high point with thirteen sentences in 1369 alone, but after 1377 the destination does not appear anymore. ${ }^{48}$ It quickly disappeared just as suddenly as it appeared, and it is only half a century later that a second, crucial piece of evidence pertaining to the nascent cult of Saint Leonard appears: in the course of the 1430s the town institutes a procession on Whit Monday. It is on this occasion - first referred to in 1437 - that the statue of Saint Leonard was carried around. ${ }^{49}$ This yearly event would grow out to be a fundamental characteristic of Zoutleeuw's devotional life.

The origin of the procession neatly corresponds to the completion of a separate chapel for Saint Leonard within the Zoutleeuw church, extending the honor of the temporary ritual into a permanent architectural framework. Already around 1355 construction work had begun at the southern transept, a part that initially ended in a portal, still visible today. Later, however, the building was extended further southward into an adjacent yet distinct room that would become Saint Leonard's chapel (Sijnte Leonarts choer, fig. 4). ${ }^{50}$ A spiral staircase in the southwestern corner of the transept leads to the floor immediately above the chapel proper. The space, equipped with two hearths, five windows and a sink, is subdivided into separate rooms by wooden partitions. In the midst of a jumble of nineteenth- and 
twentieth-century graffiti on the planks, one large but only partly legible inscription stands out, the most reasonable reading of which seems to be:

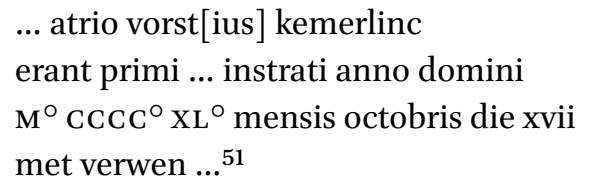

The date of 17 October 1440 evidently serves as terminus ante quem for the completion of the chapel beneath. It has been suggested that the inscription referred to the first occupants of the rooms, which were possibly designed to house pilgrims. ${ }^{52}$ Sleeping in the immediate vicinity of cult objects was indeed common practice. In Vorst, for instance, pilgrims are known to have slept in front of Saint Alena's altar, and similar cases have been signaled in nearby pilgrim churches in Aarschot and Oplinter. ${ }^{53}$

However, it more likely served as a commemorative inscription documenting the completion of the construction itself, rather than being the graffiti of pilgrims who lodged there. Texts referring to distinct phases in the building process are common in medieval churches, and multiple painted or engraved examples are known throughout Europe. Recent research has demonstrated how they contributed to the promotion of a shared civic memory by commemorating the parties involved in the construction works and by emphasizing the veracity of the claim that was made in the text. ${ }^{54}$ Examples preserved in the Low Countries testify to that practice. Sometimes they document the start or completion of a campaign, such as in Leuven (1234 and 1305), Utrecht (1321 and 1382) and Tongeren (1442), or the installation of parts of the interior and its subsequent first use, such as the baptismal font in Handzame (1400). Some refer to the stonemason or the master builder in charge of the works, like the examples preserved in Aarschot (Jean Piccart, 1337), Drogenbos (Jan van Lier, c. 1350) and Peer (Jan Groetheers, 1422), whereas others include the names of churchwardens (Berlaar, 1353) or the reigning abbess (Notre-Dame de Soleilmont, 1496). ${ }^{55}$

Evidence suggests that the three words on the first line are indeed the names of the people involved in the chapel's completion. Kemerlinc likely refers to priest and canon Godfried Camerlinck who held the office of steward of the collegiate chapter between 1431 and $1478 .^{56}$ Atrio, furthermore, was the Latinized surname of the important Van de Kerckhove family. A Petrus and Reynerus Van de 
Kerckhove alias de Atrio are both documented as aldermen and burgomasters in town in the 143 os and $14405 .{ }^{57}$ Finally, a convincing argument can be made for identifying the remaining name - Vorstius - as Sulpitius van Vorst (c. 1375-1439), the famous master builder from Leuven. His involvement in the constructions in Zoutleeuw remains undocumented but is likely, especially since his pupil and successor Mathijs de Layens (d. 1483) is securely recorded as principal master builder in Zoutleeuw in the 145os. De Layens took over the lead of almost all of the construction sites in the region that were once headed by Van Vorst - including the churches of Saint Peter in Leuven, Saint Sulpice in Diest and Our Lady ten Poel in Tienen - and it is reasonable to assume that the church of Zoutleeuw was among them too. In October 1440 Van Vorst was recently deceased, but the inscription could nevertheless still refer to his responsibility for that particular part of the church. ${ }^{58}$ Referring to three individuals involved in the completion of Saint Leonard's chapel - a member of the town council (either Petrus or Reynerus van de Kerckhove alias de Atrio), a representative of the chapter (Godfried Camerlinck) and the master builder (Sulpitius van Vorst) - the inscription commemorates a key event in the cultic history of Zoutleeuw's patron saint.

The chapel and its altar were consecrated soon after this completion on 21 October 1442, and dedicated to Saint Leonard, the 11.000 Virgins and All Saints. This event would be commemorated yearly in the so-called 'four Masses' in honor of the altar's patron saints: on the feast day of Saint Ursula and the 11.ooo Virgins (21 October, coinciding with the feast of consecration), on Sunday before All Saints, on All Saints' Day (1 November) and on the feast of Saint Leonard (6 November). These Masses were elaborately celebrated by a priest, deacon and subdeacon, accompanied by organ music and the chapter school choir and announced by persistent bell-ringing. It was also on the occasion of the consecration that the hope to receive pilgrims was clearly expressed for the first time. The foundation charter, issued by Denis Stephani, Bishop of Ross (act. 1436-1458) and suffragan to the Liège Bishop, provides a considerable amount of days of indulgence, 40 of which were to be earned at the saint's feast day and at Whit Monday, when the saint's statue was carried around in the recently instituted procession. In relation to the latter, it was explicitly stated that the indulgences were given 'so that the faithful Christians will be encouraged in their devotion, prayer and pilgrimage, and that they will flock together in the chapel. ${ }^{59}$ Any possible pre-existing veneration of Saint Leonard had now become an officially sanctioned cult in Zoutleeuw. 
Part or all of the funding for this chapel was possibly provided by a lay couple. In a marginal note next to his 1734 transcription of the act of consecration, priest Daniël Godts (1703-1797) stated that 'Joannes de Katen and Maria, his wife, funded this chapel and Masses in it [on] 23 September 1442' ${ }^{60}$ The conspicuous absence of De Katen's name in the act of consecration seems to exclude the possibility that the chapel was related solely to the family's personal memoria, but it is plausible that the couple significantly contributed to its completion. As the construction of the chapel probably was already underway for about a century, their intervention might have been motivated by the fact that the project had remained uncompleted. Comparative analysis of the cutting techniques of the stones used in the chapel led architectural historian Frans Doperé to date the upper parts of the eastern, southern and western walls to 1410 at the earliest. ${ }^{61}$ This would mean that the chapel, begun around 1355, remained uncompleted for at least 55 years, and this might account for complementary private funding. Strikingly, this closely corresponds to the two clusters of evidence documenting the nascent cult of Saint Leonard: the first in the 1350s and 136os, the second in the 143 os and 1440s. By 1442, however, Saint Leonard was finally able to receive pilgrims in a proper chapel, especially designed for that purpose. And soon after the churchwarden accounts would start to register the fortunes of this devotion.

\section{The Fortunes of Devotion: Offerings}

The snippets of information recounted above suggest an evolution towards official approbation, but say nothing about how successful and widespread the veneration of Saint Leonard in Zoutleeuw was. The construction and consecration of the chapel were of course essential steps towards institutional recognition, but they might obscure pre-existing movements of popular piety that remain under the radar. Nor does episcopal support necessarily constitute a successful cult. It is by no means the purpose of the preceding overview to suggest that the actual cult only took off after the 1442 consecration. Rather, the evidence at hand confirms earlier observations of the cyclical movements of the popularity of individual cult objects. Patrick Geary called this the 'careers' of relics, which consist of successive periods of intense veneration alternating with times of general neglect. ${ }^{62}$ The same might have been the case at Zoutleeuw, but the lack of churchwarden accounts and other sources referring to 
the statue or the Whit Monday procession before $145^{2}$ makes it very hard to assess its popularity.

The silence of sources can also be instructive, however. This is particularly true for the lists of shrines that can be deduced from local law courts' sentences of judicial pilgrimages. The localities assigned coincide with the most renowned pilgrimage destinations, as important shrines with international reputations such as Rome, Milan, Santiago de Compostella, Rocamadour and Cologne figure frequently in the condemnations. Authorities mostly chose such faraway destinations to remove the condemned from local society for a sufficient period of time, but the destinations that were chosen within the Low Countries equally seem to reflect a regional hierarchy. Key shrines such as Geraardsbergen, Halle, 's-Hertogenbosch and Maastricht indeed occur most frequently. ${ }^{63}$ In relation to Zoutleeuw, however, only one other sentence is known apart from the previously mentioned series of judicial pilgrimages from Maastricht (1367-1377). On 7 September 1520 two men from Neeroeteren were condemned to a pilgrimage to Saint Leonard, proof of which they brought back on 17 September of that year. ${ }^{64}$ This rather late date, and the otherwise complete absence of Zoutleeuw from records is striking. Between 1403 and 1516, the city of Brussels sent several convicts to Tienen and Sint-Truiden, but Zoutleeuw, which is located right in between these towns, is never mentioned ${ }^{65}$ Nor was it chosen in the city of Turnhout, for instance, which nevertheless sent convicts to Aarschot and Wezemaal, which are a mere 3 o or 35 kilometers away from Zoutleeuw. ${ }^{66}$ The same is true of other cities such as Antwerp, Leuven, Tienen or Vilvoorde. ${ }^{67}$ In this respect it is interesting to note that the overall high point of the practice of judicial pilgrimages in the Low Countries was in the fifteenth century, and had almost completely disappeared early in the next century. The Brussels peak in the 1430s, for instance, thus definitely preceded the 1442 consecration of the Zoutleeuw chapel. ${ }^{68}$ It could therefore be argued that Zoutleeuw's conspicuous absence is an indication of its relatively late development as renowned pilgrimage site in comparison with other localities figuring in the lists.

The churchwarden accounts confirm this chronology. Whereas the desire to receive pilgrims was expressed in the 1442 consecration charter of Saint Leonard's chapel, they only occur in the accounts nearly four decades later. Until then, payments to an extensive group of people formed yearly recurring costs for the Whit Monday procession, including trumpeters, pipers, lutenists, actors, walk-ons, jesters, bell-ringers and torch-bearers, either paid in cash or in wine, beer, 
bread, sausages and cheese. Pilgrims were only included in this rich list during the celebration of 1480 , and from then on were rewarded with drinks and food on a yearly basis. ${ }^{69}$ This does not necessarily mean that pilgrims were not present in Zoutleeuw before, because it is certainly possible that a separate record was kept, that such costs were not specified in the accounts before or simply that there was no money involved. ${ }^{70}$ Yet, the fact that the churchwardens started to explicitly register it suggests an intensification at the very least. Furthermore, from 149 o onwards accounts also record the amount of grain used for the baking of the bread that was distributed to the pilgrims at Pentecost. This quickly rose from the initial 2 halster (c. 60 liters) in 1490 to 2,5 halster (c. 75 liters) in 1492, 3 halster (c. 90 liters) in 1493, finally arriving at 4 halster (c. 120 liters) in 1496 - an amount that would be maintained during the following years. ${ }^{71}$ It is impossible to quantify these figures in absolute numbers, but it is very likely that the increasing amounts of grain reflect a growing number of pilgrims. Most importantly, the 148 os also saw the first clear and indisputable indications of miracles worked by Saint Leonard in Zoutleeuw. In April 1484 the sextons were paid to ring the bells after a miracle had happened, and in May 1488 the churchwardens gave 7 stuivers to the pilgrim who had been miraculously released by Saint Leonard. ${ }^{72}$ All this evidence clearly suggests that it was only in the course of the last decades of the fifteenth century that the church grew out to be a pilgrimage site of regional importance.

\section{Assessing Devotion: Offerings in Kind}

Increasing offerings reflect this rising popularity, the importance and variety of which is demonstrated by contemporary imagery. The panel concluding the cycle on the life and cult of Saint Rumbold in Mechelen (fig. 19), for instance, is illustrative of the fact that donations mostly included items that were useful to the church in question, such as grain, wax or wine, which could either be sold or used during Mass. Two canons, sitting in front of the saint's shrine, are depicted receiving various kinds of offerings given by pilgrims in return for the kissing of the saint's reliquary. Previous visitors left coins, which lay scattered upon the table, and the pilgrim depicted in the act of kissing is handing over a wax candle and a bag of what is probably grain. A woman to his right holds a caged chicken, while on the left a man arrives with a sheep slung around his neck.

Ex-votos constitute a particular category of offerings in kind. These are offered objects or images that always stood in direct relation with the favor that was asked of a saint, or with a miracle that 


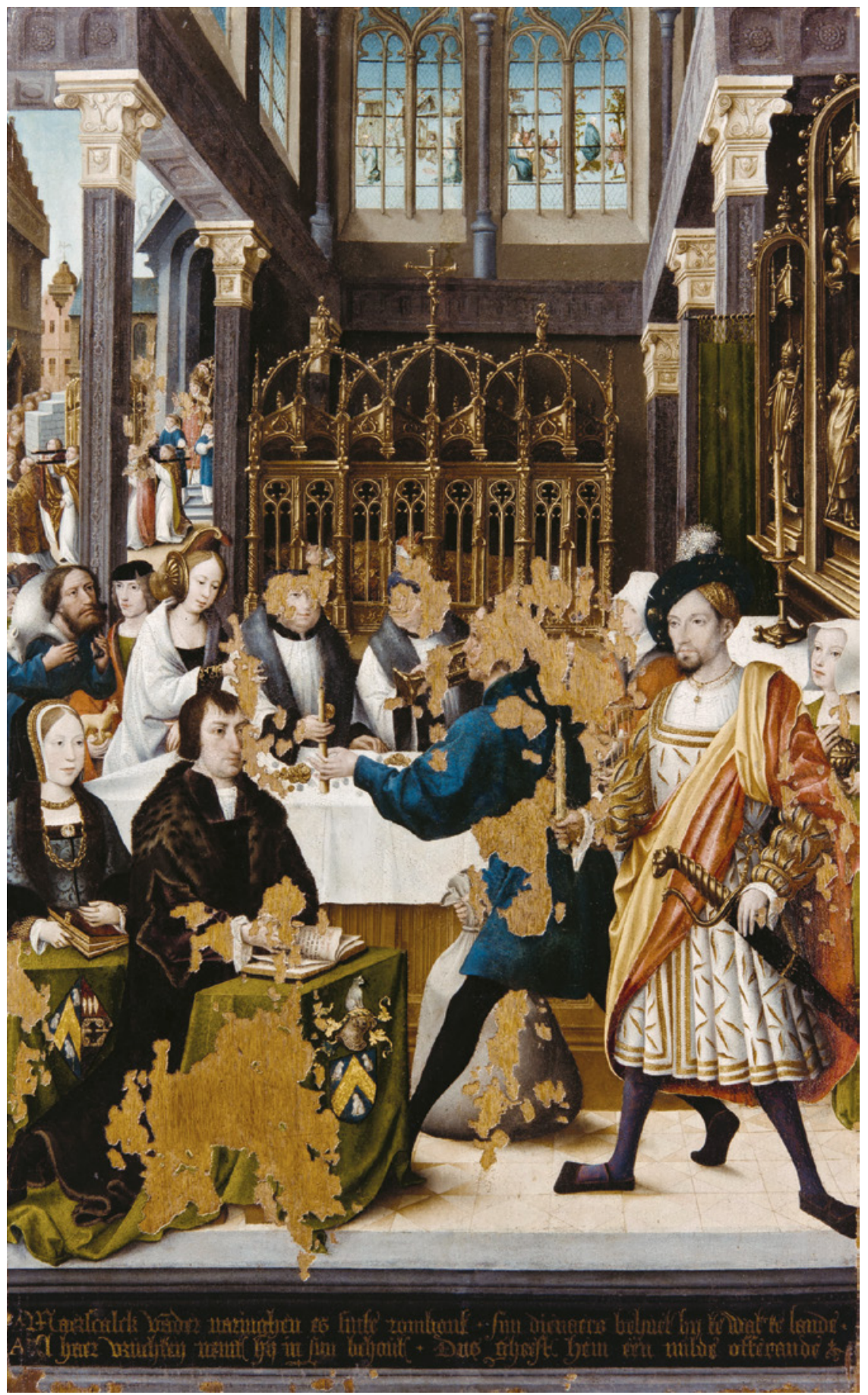

FIGURE 19 Master of the Legend of the Magdalen, The cult of Saint Rumbold in Mechelen, with Jean Micault and his wife, c. 1500-1510, Mechelen, cathedral of Saint Rumbold

(C) KIK-IRPA, BRUSSELS 
had happened. Pilgrims hoping for the healing of their legs would generally offer an image of that body part and cripples that were able to walk again often left their crutches at the shrine. As these objects were often made of materials that were easy to adapt, such as wax or metal, they could either be reused or cashed in by the fabrica ecclesiae. Still, they often remained untouched at their places in or near the sanctuary, because large quantities of ex-votos functioned as striking proofs and illustrations of the popularity and power of the saint to whom they were dedicated. ${ }^{73}$ A scene depicted on the central outer wings of the 1516 Antwerp altarpiece in Västerås (Sweden) illustrates the prominent display of precious gifts hung on a rod immediately above the altar (fig. 20, compare with figs. 24, 54, $71 \& 135$, and p. 74). In Zepperen the donated crutches were even repeated in trompe l'oeuil mural paintings in Saint Genevieve's chapel, just beneath a cycle depicting her vita (fig. 21).

Similar practices are extensively documented at Zoutleeuw. The church still possesses a fifteenth-century offertory box for grain (fig. 22) and the accounts sporadically registered the amounts donated, recorded most regularly in the early decades of the sixteenth century. ${ }^{74}$ Other materials that were offered include wool or flax, but also animals such as pigs or poultry. ${ }^{75}$ The accounts equally document ex-votos. In January 1498 a rod for iron gifts - a material that might well have been particular to the cult of Saint Leonard - is installed near the chapel, which was followed by another rod for wax figurines in June $1509 .{ }^{76}$ Such objects, including figurines, legs and crutches, are clearly depicted as hanging near the statue on the 1612 painting commemorating a miraculous healing worked by Saint Leonard (fig. 128). The most striking ex-voto gift recorded in the accounts, however, is a suit of armor hanging in front of Saint Leonard in 1491, which was clearly cherished, as an armorer was paid to clean it. On the Västerås panels a similar gift proudly hangs above the altar (fig. 20). Yet, even such prestigious gifts had monetary value and two years later the wardens sold the armor for 2 Rijnsgulden. ${ }^{77}$ These offerings and the documented accommodation for votive gifts around 1500 are evident consequences of the posited intensification of pilgrimage in Zoutleeuw in the later decades of the fifteenth century.

\section{Quantifying Devotion: Offerings in Specie}

The importance of offerings in kind suggests that the wide range of possible expressions of piety cannot and should not be reduced to devotional liberality alone, and the present study emphatically does not posit a direct proportional relationship between financial gifts 
FIGURE 20

Anonymous (Antwerp),

Passion altarpiece, central outer wings, 1516, Västerås, Cathedral

(C) KIK-IRPA, BRUSSELS

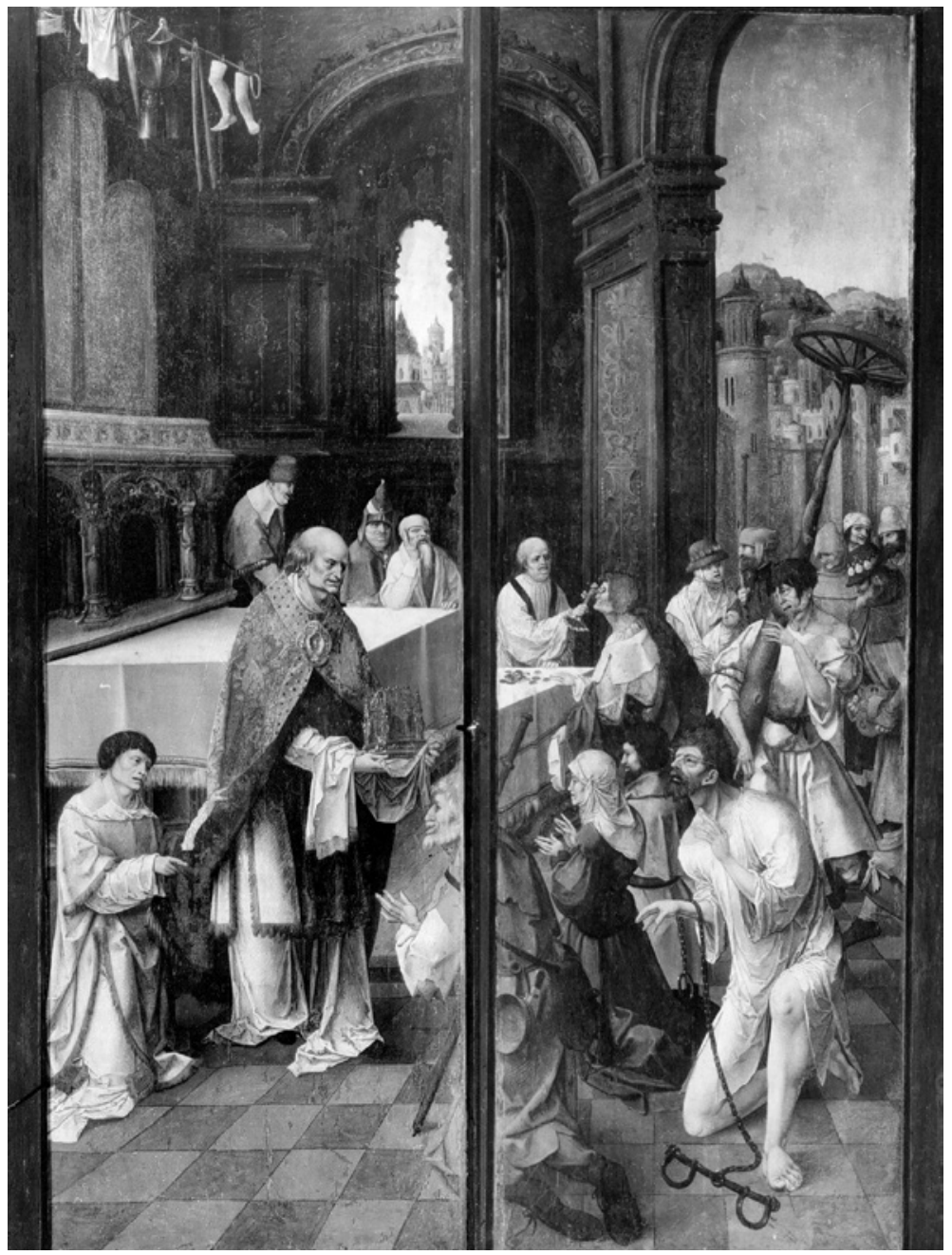

and devotion. However, the historiographical debate on piety in the Low Countries has mainly been based on the evolution of monetary income figures. The financial analysis of offerings is indeed one of the few ways in which devotion can be quantified to any extent, at the same time allowing us to trace its evolution over a longer period of time. In Zoutleeuw, the revenues from devotional gifts - both in specie and in kind - were registered yearly by the churchwardens in a separate section with extraordinary income, i.e. a collection of diverse revenues that were not structural in nature, contrary to the more or less fixed income from taxes or the rents of houses and meadows. The monetary revenues that were demonstrably devotional in nature and which can be followed in the long term mainly 


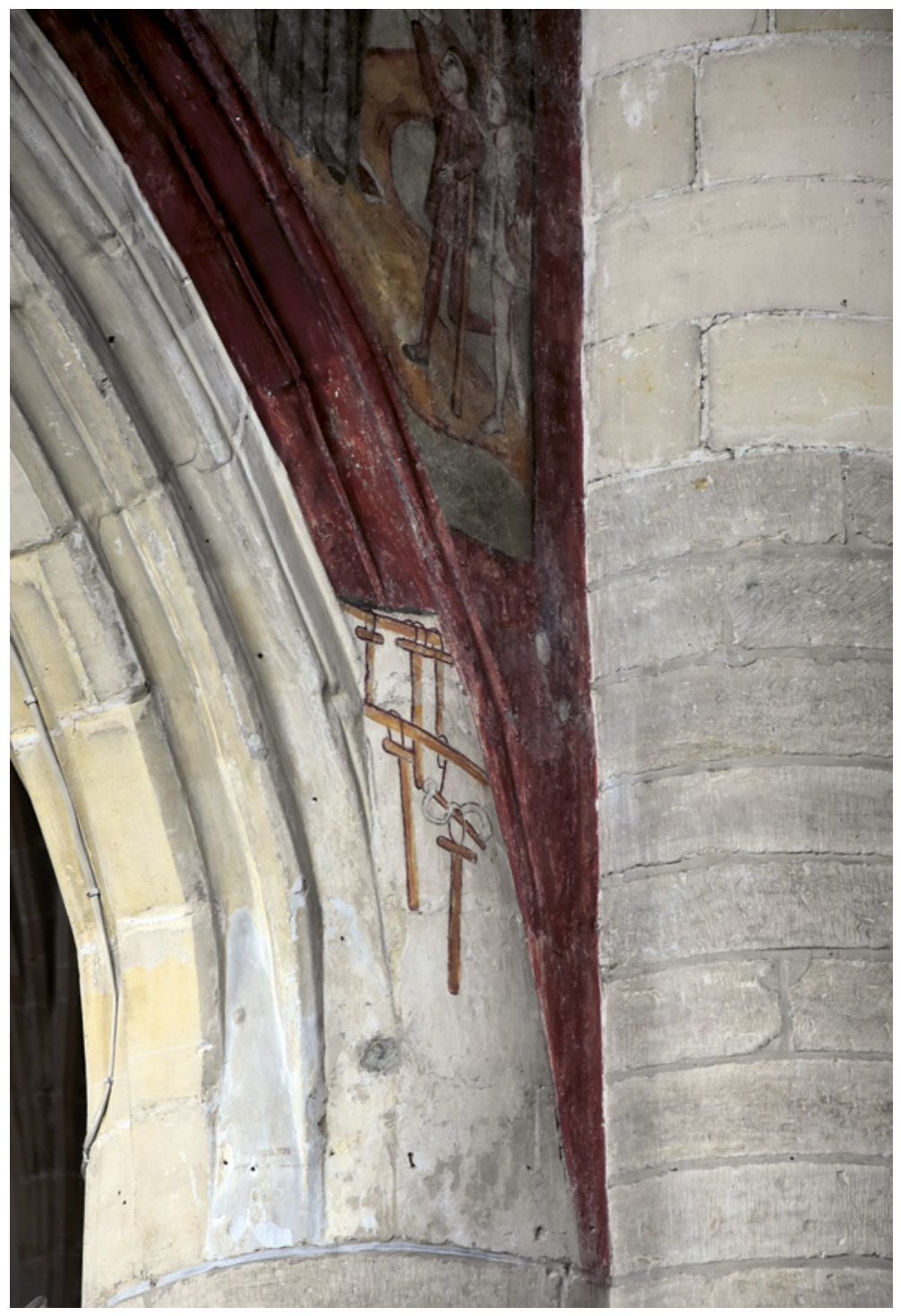

stem from two sources: gifts in an offertory box (stock or kist), and collections on feast days.

The average village church in the Low Countries probably counted only one offertory box, but urban churches often contained many more, mostly located near entrances or altars. Kortrijk's church of Saint Martin, for instance, had no less than twelve boxes. ${ }^{78}$ The Zoutleeuw church initially had two installed. ${ }^{79}$ The earliest records are rather vague on their placement in the church, but certainly from 1478 onwards one stood in Saint Leonard's chapel (Sijnte
FIGURE 21

Anonymous, Mural painting

depicting crutches as ex-votos in trompe l'oeuil, 1509,

Zepperen, church of Saint

Genevieve

PHOTO: AUTHOR 


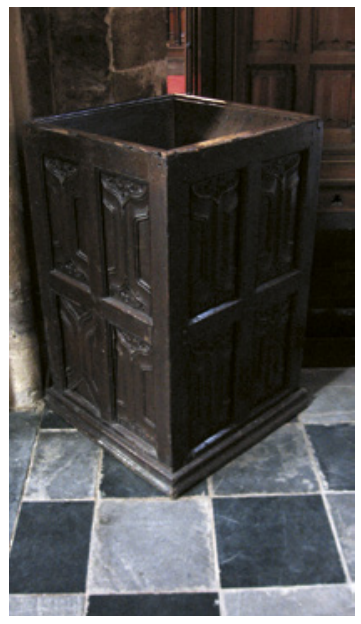

FIGURE 22

Offertory box for grain, c. 1500, Zoutleeuw, church of Saint Leonard PHOTO: AUTHOR
Leonaerts coer), while the other was likely placed just outside the chapel doors. ${ }^{80}$ From 1497 onwards two other boxes are documented that in later years were mostly located near the altar of Saint Blaise at the rood loft and the Holy Sepulcher (fig. 23). In 1555, finally, the churchwardens took control of a box belonging to the Lauds of the Holy Sacrament, installed near the altar of the Holy Cross, which was probably located near the sacrament house. ${ }^{81}$ The boxes were emptied two to four times a year, but no regularity in the moments or the number of times can be established, and it is impossible to infer seasonal variations. Apart from the revenues from the offertory boxes, money was also collected on feast days. Especially the collections at Candlemas (2 February), at the occasion of Saint Leonard's procession on Whit Monday and on the feast of Saint Leonard (6 November) constituted yearly recurring entries. In addition to these two main categories of the offertory boxes and the collections at feast days, sporadic donations were also made for specific purposes such as the casting of a new bell, the polychromy of sculpture or the acquisition of altarpieces. ${ }^{82}$

All these donations were both anonymous and voluntary. In principle, this combination makes them more representative of lay piety than revenues from sacramental obligations, which Toussaert based most of his findings on. ${ }^{83}$ It is important, however, that both these terms should be nuanced and contextualized. Firstly, 'voluntary' is a notion open to interpretation in this period. Churchwardens or local clergymen are known to have actively collected offerings from pilgrims and visitors, and donation was also implicitly encouraged in contemporary devotional books. A case in point is the printed booklet issued around 1518 by the shrine of Saint Alena in Vorst, the narratives in which recount miracles happening after pilgrims had made their offering, with or without encouragement from a present churchwarden. ${ }^{84} \mathrm{~A} 1527$ panel with scenes from her life and cult (fig. 24) indeed shows pilgrims of various social strata kneeling and praying in front of the altar, next to which a churchwarden sits to receive the gifts. Other paintings similarly represent clergymen (figs. 19 $\& 20$, see also fig. 71 ), and their presence near the shrine might have urged visitors in donating money. ${ }^{85}$

Furthermore, guilds' articles of association often included stipulations that obliged their members to make an offer on the feast day of their patron saint. ${ }^{86}$ This was the case with the Zoutleeuw arquebusiers' guild which was founded in 1515 and devoted to Saint Leonard. The guild's extended statutes, issued in 1537, mention that 'every member will go to the church on Saint Leonard's day to attend 


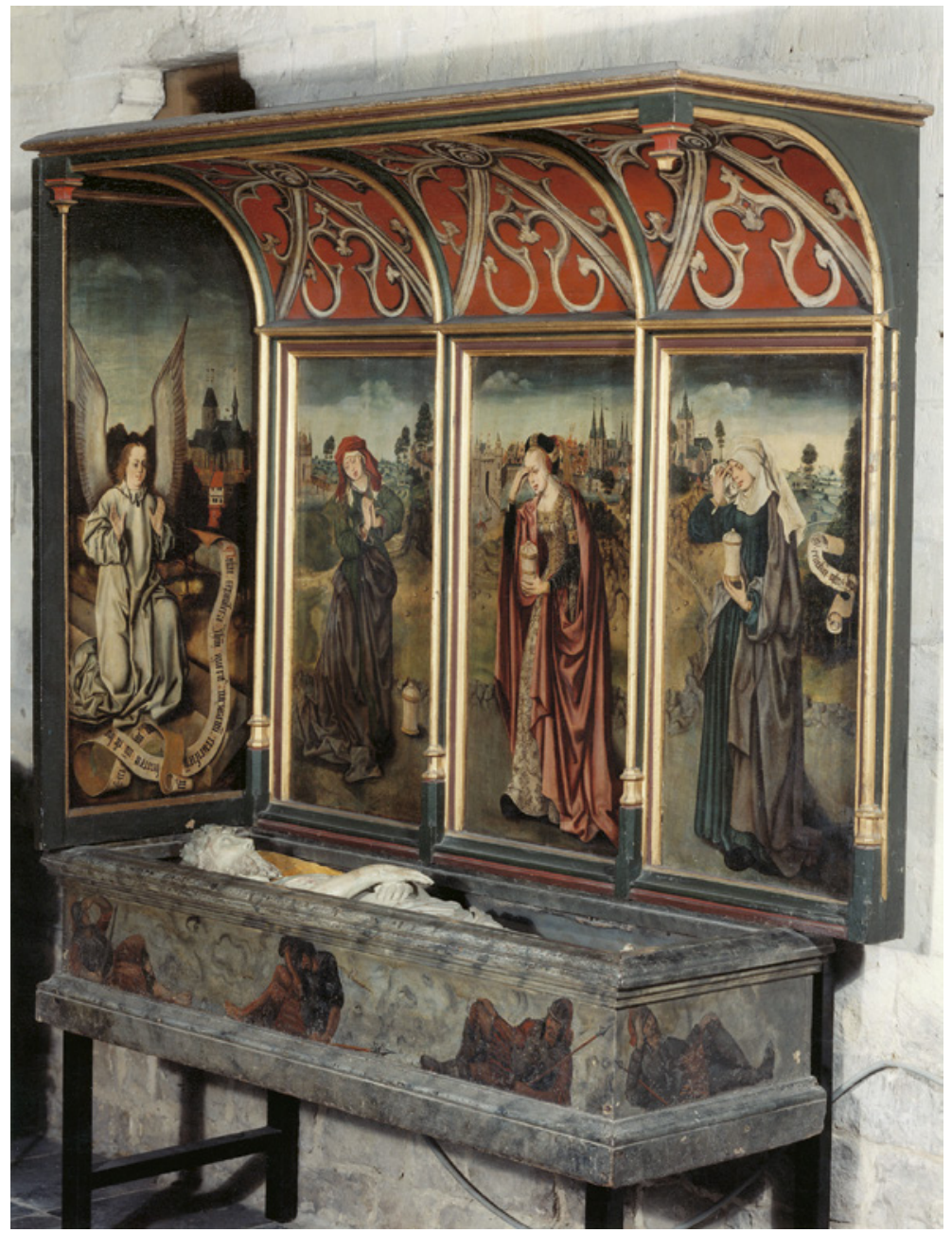

a sung Mass that the guild will provide for in Saint Leonard's chapel, and that everyone will bring his offer there. ${ }^{87}$ It is nevertheless likely that money collected at these instances was destined for the guild's own purse and such offerings would, as a consequence, not have been recorded in the churchwarden accounts. Membership furthermore was not available to everyone and it is far from certain that such statutory obligations were actually observed. Moreover, every member or pilgrim determined how much he or she offered. All in all, the voluntary character of the money offered counters any possible critique that changing revenues would reflect evolutions in people's wealth rather than in their devotion. It is undesirable to assume a directly proportional relationship between offered money and devotion, but it is equally wrong to posit a similar relation between increasing wages and increasing devotional revenues.
FIGURE 23

Jan Mertens and Lodewijk de Raet, Holy Sepulcher, 1490-1504, Zoutleeuw, church of Saint Leonard (C) KIK-IRPA, BRUSSELS 


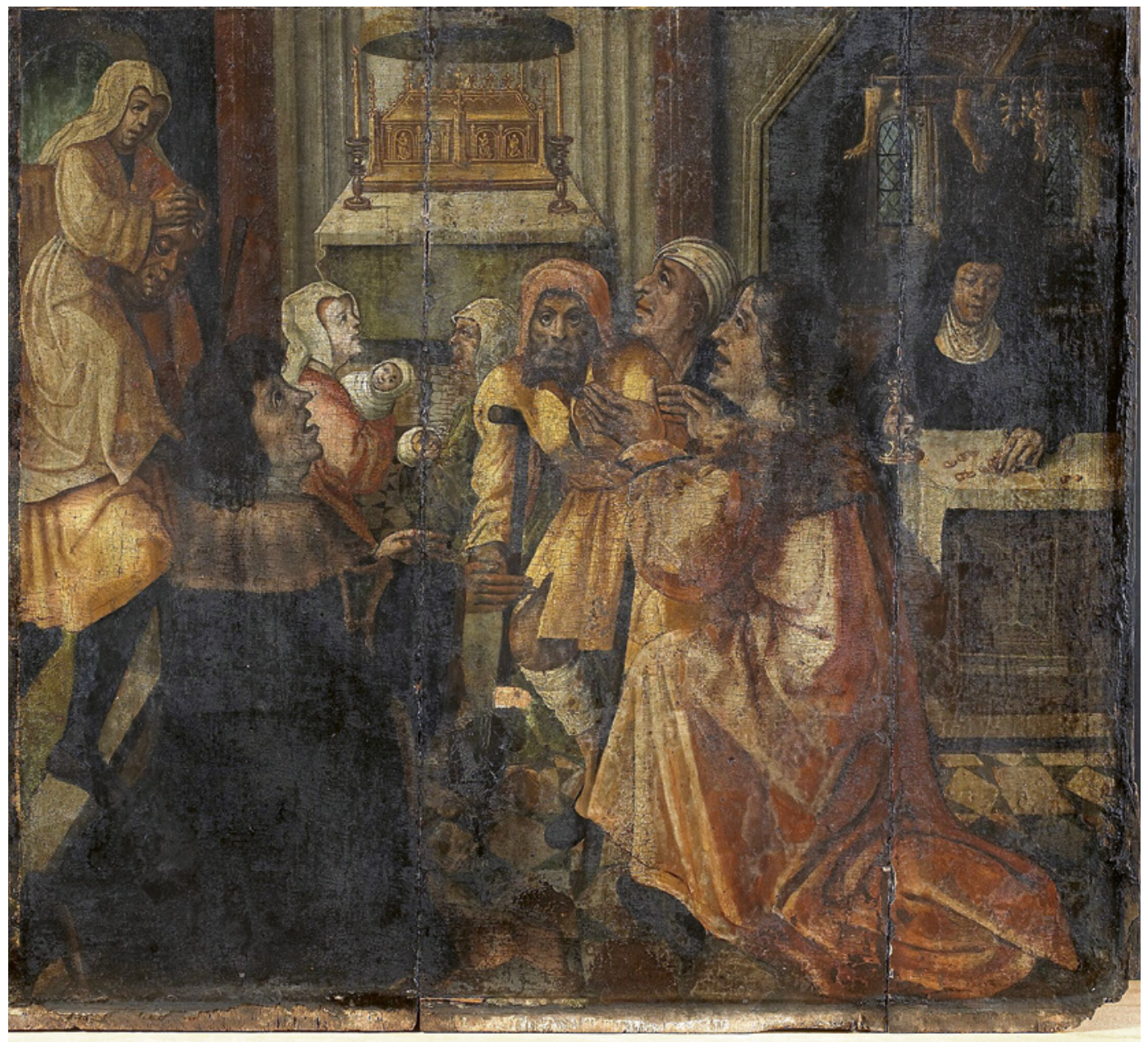

FIGURE 24

\section{Anonymous, Pilgrims at the} shrine of Saint Alena, from a panel depicting scenes from her life and cult, 1527 , restored in 1638 , Vorst, church of Saint Denis (C) KIK-IRPA, BRUSSELS
Secondly, donations were, to a large extent, anonymous. Other parameters that have been used to map the evolution of certain devotions, such as foundations of (anniversary) Masses or testamentary dispositions, are biased, because they were likely influenced by other motives such as social prestige. After all, the individual memory of the founder was their raison d'etre. ${ }^{88}$ In the Zoutleeuw accounts, personal monetary gifts were generally recorded explicitly as such, including the name in question, and as a rule they were considerably higher than other gifts. Interestingly, even if smaller monetary gifts - under one gulden - were not put in the offertory box, they were mostly registered as anonymous, usually identified as 'from a good man' or 'a good heart'. ${ }^{89}$ It might be suspected that the churchwardens simply did not deem such low gifts worthy to be registered 
nominatim, but other examples make clear that this could definitely happen at the express wish of the giver, presumably because of pious reasons. In 1508, for instance, a woman modestly contributed to the polychromy of the altarpiece of the Illustrious Brotherhood of Our Blessed Lady from 's-Hertogenbosch, but desired to remain unknown. 90

Delineating the revenues related to the cult of Saint Leonard from the Zoutleeuw accounts provides an idea of how it evolved through time. They are comprised of the gifts in the offertory boxes near Saint Leonard's altar throughout the year, the revenues from the collection on his feast day (6 November), and the money collected at the Whit Monday procession when the statue was carried around through town. The cult's share of the total of devotional revenues is uncertain in the earliest years however, as the accounts do not specify where precisely the money came from. In most cases the churchwardens just recorded a total sum gathered from both boxes, without making clear just how much had been offered in honor of Saint Leonard. The figures from the earliest accounts therefore need to be considered as minimal, and only in the account of 1479 do the entries contain precise references to how much the churchwardens found in the box next to Saint Leonard's altar. This specification in itself suggests that the financial importance of these revenues was increasing at that moment. Furthermore, the rise towards 1500 is clear, and there is a striking peak in the account of 1483 . From the late 1470 onward the share of the revenues generated by the cult of Saint Leonard within the total amount of devotional revenues gradually grew and from the late 149 os onwards it took up a portion of 80 to nearly $100 \%$ (graph 1 ). The steadily increasing mentions of foreign coins between the monetary offerings from 1500 onwards further suggests a broader, interregional interest. ${ }^{91}$ Subdividing the total revenues into its constituent parts makes clear that the money collected at the occasion of the Whit Monday procession formed the most important share by far (graph 2). Next to the more or less fixed income from taxes or the rents of houses and meadows, the cult of Saint Leonard grew to become an ever more important financial source for the Zoutleeuw fabrica ecclesiae. Towards the end of the fifteenth century both categories had the same worth, and the latter even surpassed the former in the first decades of the sixteenth century (graph 3 ).

These trends cannot be explained by monetary depreciation, inflation and financial policies. Rises and declines are not only visible in the curve depicting the nominal figures, but also when it is 
converted by means of a calculated real wage index (graph 4). ${ }^{92}$ The changing proportion between the revenues of the cult of Saint Leonard and the fixed revenues of the fabrica ecclesiae is telling too: whereas the fixed income remained more or less stable until 1478, the revenues from the cult had already been increasing for some years. The temporary regression in the late 148 os and early 1490 os probably has to be explained by the fact that in September 1488 the town of Zoutleeuw joined the County of Flanders, together with several other Brabantine cities, in rebellion against Maximilian of Austria. As a consequence, the town and its immediate surroundings found itself in a state of war, the disastrous effects of which they soon experienced..$^{93}$ In addition, the rebel provinces were subjected to a pernicious financial policy, pursued by the central government to finance the war. But such factors cannot account for the rise that preceded these events. Maximilian's first currency reforms only dated to 1485 , more than a year after the first peak. ${ }^{94}$ Neither can the increasing revenues be explained by demographic evolutions, as population figures of Zoutleeuw and the Hageland region as a whole show a clear downward tendency towards $1500 .{ }^{95}$ The assembled data thus depict an evolution in devotion or pious expression. Possibly suggesting an increasing piety on the part of the population, they certainly reveal a rising devotional liberality in the last decades of the fifteenth century. It is therefore worthwhile to have a look at the agency of the churchwardens in this period of flux. Though variable, the cult of Saint Leonard demonstrably became an important source of income for the Zoutleeuw fabrica ecclesiae and all the evidence at hand suggests that the later 1470s and early 1480 marked an important turning point. How did they respond to these trends, and how must the 1476-1478 altarpiece of Saint Leonard be seen within this changing context?

\section{The Promotion of Devotion}

\section{Cultic Awareness}

The Zoutleeuw churchwardens were clearly conscious of their patron saint's increasing popularity. This cultic awareness is expressed by their progressively meticulous financial record keeping, and was eventually manifested in material form in the construction of the churchwardens' room (meesters camer or camer der fabrijcken), begun in April 1479 (figs. 4 \& 25). ${ }^{96}$ The acquisitions for this room - a cabinet (contoir) and a treasure chest (trisore) - demonstrate that it 


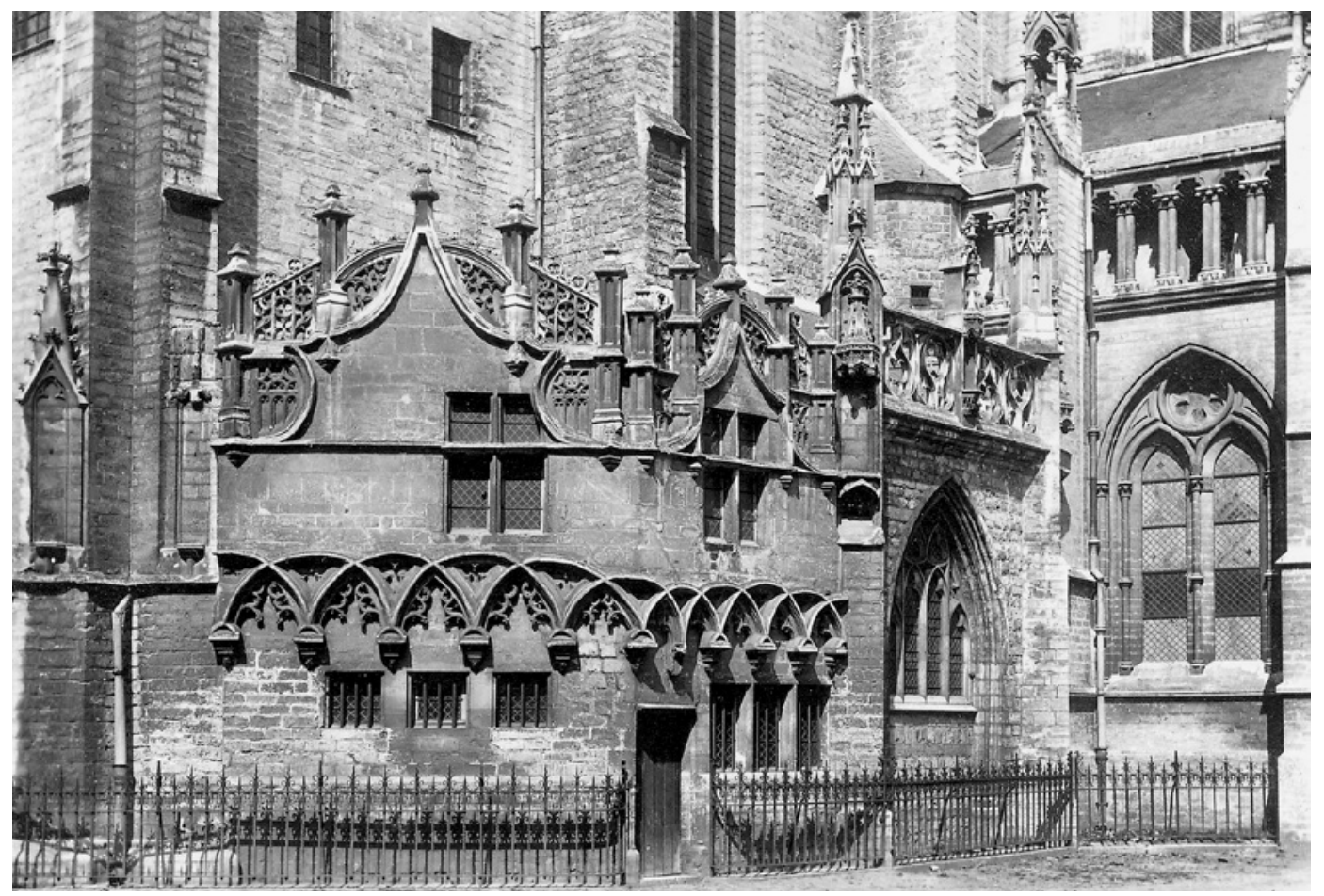

FIGURE 25

functioned as a space for administration, safekeeping and storage of their archives, books, money and other valuables, including a, now lost, precious Saint Leonard's play on parchment. It also possibly served as their meeting venue and a room where they organized meals. ${ }^{97}$ The fact that the accounts variably refer to it as 'Saint Leonard's room' (Sinte Leonaerts camere) clearly emphasizes the wardens' self-identification as the 'guardians of Saint Leonard' an office that arguably had become more important due to the increased attention to the patron saint. ${ }^{98}$ Conveniently located to the east of Saint Leonard's chapel, the room also bordered the principal entrance to the church (the parvis or poertael), before the construction of the current portal in the west front in 1525 (fig. 1). An 1851 photograph (fig. 26) and contemporary lithograph (fig. 27), both preceding the choir's radical restoration that started in 1861, still show a door in the wall between the choir and the churchwardens' room, now walled up and provided with a window. In 1453 this portal had been provided with three polychromed stone tabernacles, including figurative reliefs depicting scenes from the life of Saint Leonard (figs. $28 \& 29$ ), foreshadowing what would follow in the chapel. ${ }^{99}$
Façade of the

churchwardens' room, 1479-1480, view from the south-east, Zoutleeuw, church of Saint Leonard (C) KIK-IRPA, BRUSSELS 
FIGURE 26

Guillaume Claine, Léau,

fragment de l'église, un jour de foire, 1851, Antwerp,

Fotomuseum

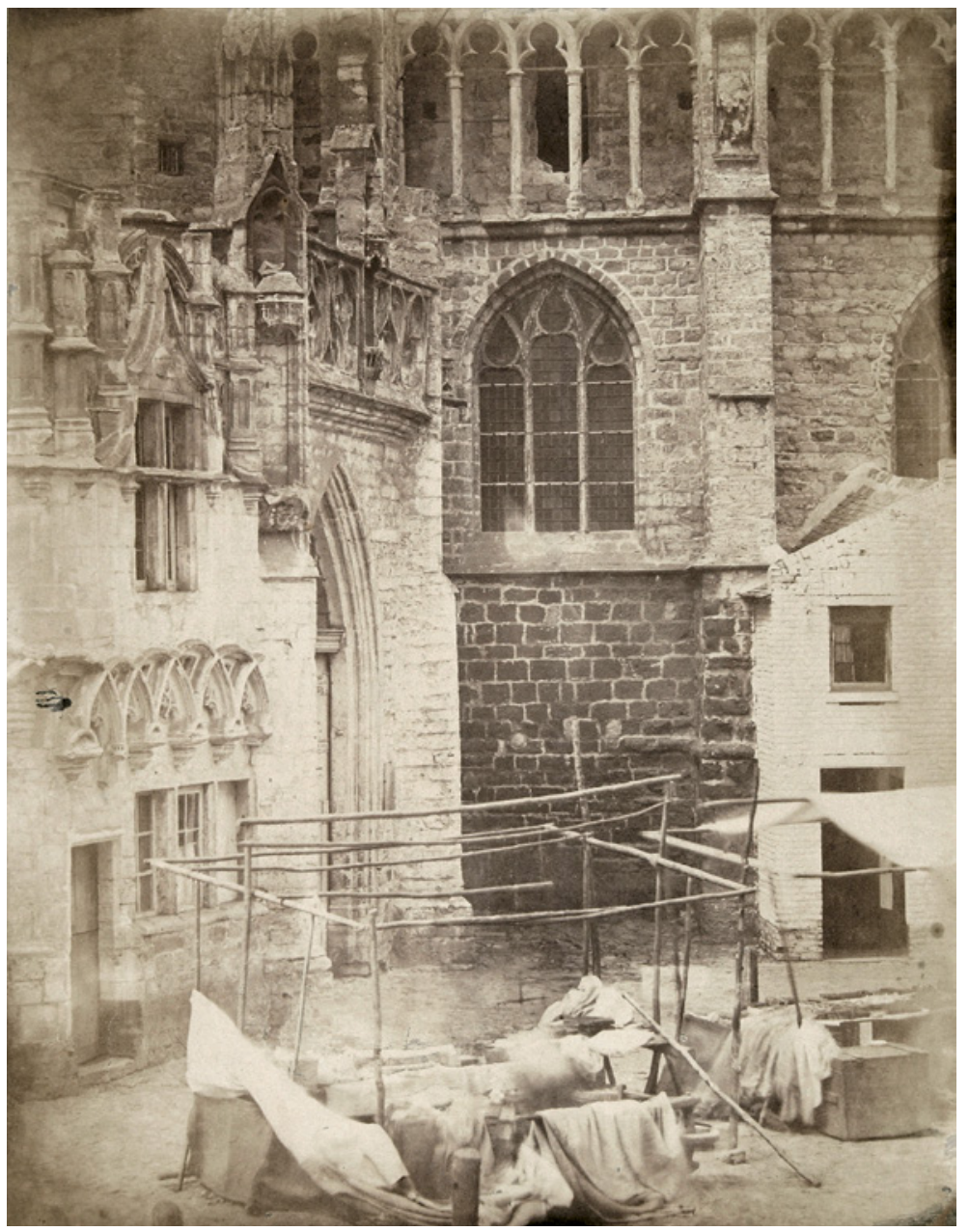

This heightened importance of the cult as well as the churchwardens' awareness of it were formally expressed in the structure. The building's facade is arguably the most conspicuously ornamented part of the whole church building's exterior. The accounts thoroughly document the acquisition of various specific decorative and structural elements from the quarry at Gobertange, including water-and dachlijsten, spersteene, sammaranden, avinckels metten perlerkens and rabats. ${ }^{100}$ In fact, this is an understated though expressive example of what Matt Kavaler has labeled 'Renaissance Gothic', a term with which he refers to the new, elaborate gothic ornaments with emphatic tracery motifs that were developed in the Low Countries in the late fifteenth century. According to Kavaler, such forms were 


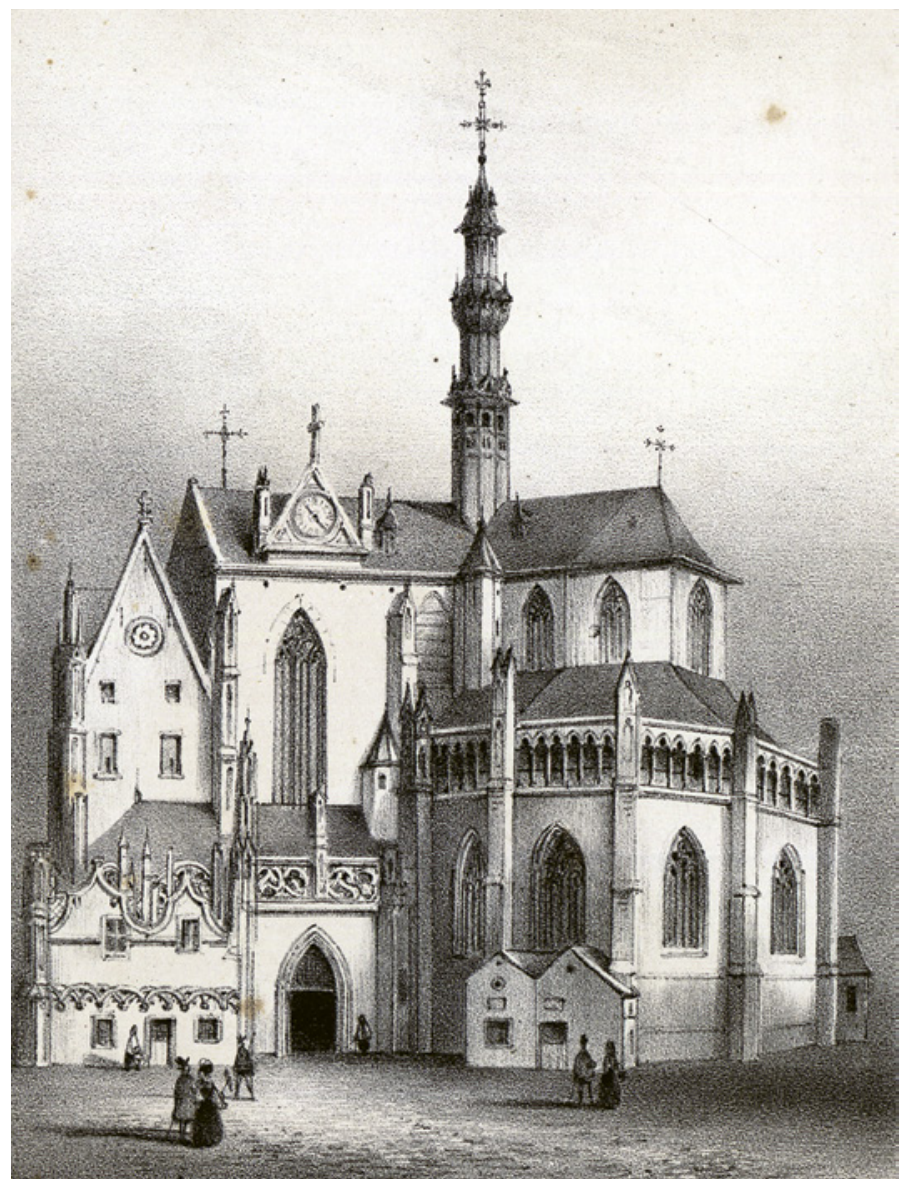

FIGURE 27

Henri Borremans et Compagnie, Vue de l'église

de Léau, c. 1840-186o, Ghent, University Library

consciously located at important places on buildings, which through 'the authority of ornament' were given an important hierarchic position within the whole of the construction. ${ }^{101}$ The gaudy decorations on the facade of the Zoutleeuw churchwardens' room thus identified the space behind it as the beating heart that ran the sacred space and thereby strongly asserted the important status of the churchwardens that gathered within. Similarly, about a decade later the liturgical chants for Saint Leonard in the newly commissioned gradual books (fig. 91) would pertinently emphasize how 'Saint Leonard's delightful name flourishes in our church'.102 The gothic tracery visually translates this very idea of devotional bloom. 


\section{FIGURE 28}

Anonymous (Brussels), The baptism of Saint Leonard, c. 1453 , Zoutleeuw, church of Saint Leonard PHOTO: AUTHOR
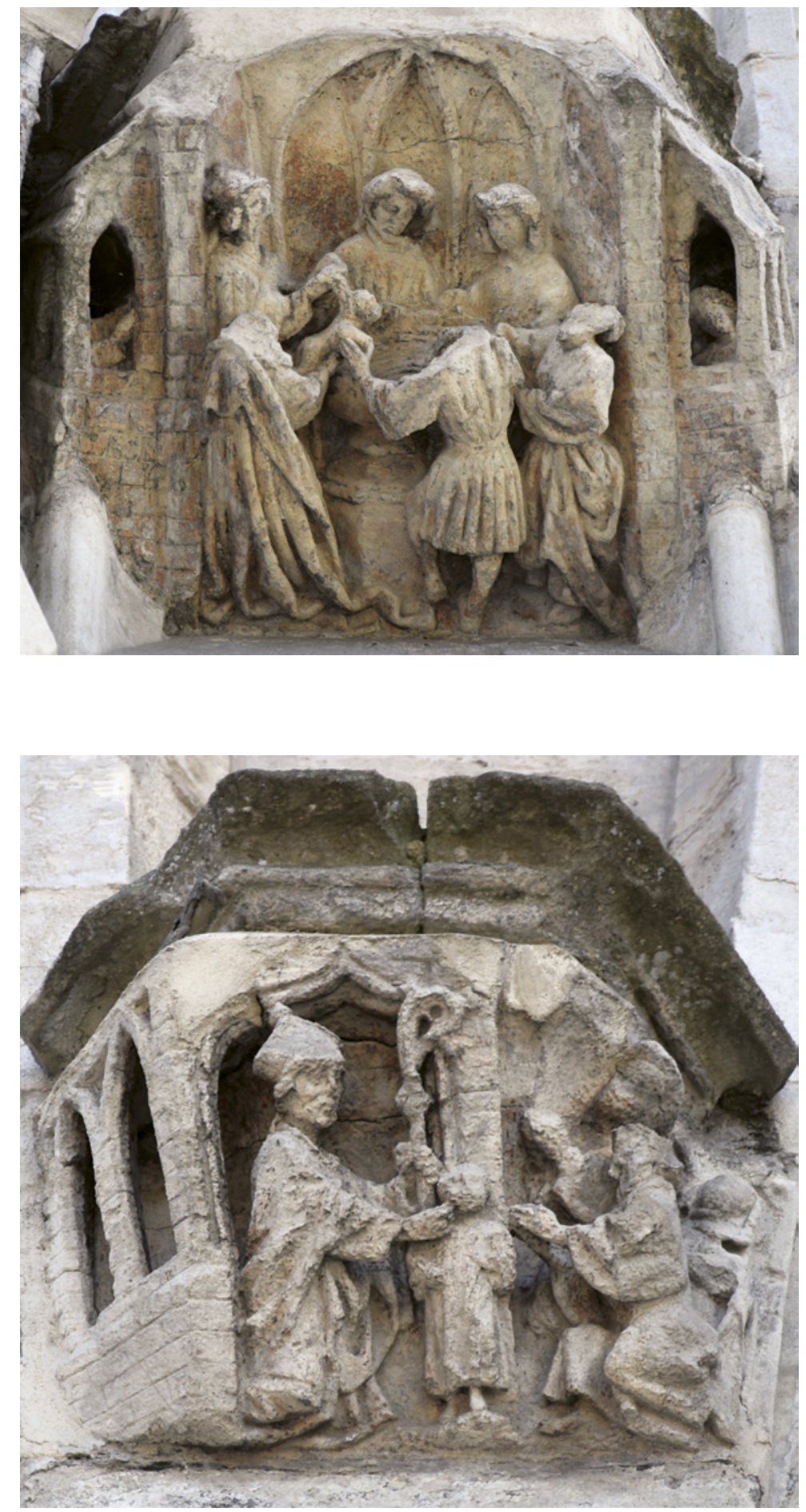

FIGURE 29

Anonymous (Brussels), Saint Leonard healing a child, c.

1453, Zoutleeuw, church of Saint Leonard PHOTO: AUTHOR 


\section{Spreading the Word: Badges and Indulgences}

The construction of the churchwarden's room coincided with the commission and installation of Saint Leonard's altarpiece. In fact, there are other strong indications that the churchwardens responded to devotional evolutions and even actively promoted the local cult of Saint Leonard in the wider region at precisely this point in time. It is not unreasonable to assume that they worked in close collaboration with the collegiate chapter in organizing this promotion campaign, because such institutions are known to have intensely cherished the cult of their patron saints and often served as principal commissioners of construction works. ${ }^{103}$ Yet, the Zoutleeuw acta capituli have not been preserved for this period and the churchwarden accounts remain silent on the chapter's role in these matters. ${ }^{104}$ Furthermore, there are no indications that the canons were entitled to part of the revenues from the cult of Saint Leonard and all of the income seems to have gone to the fund of the fabrica ecclesiae. Focus will therefore be on the agency of the churchwardens as representatives of the body that maintained and decorated the sacred space of Saint Leonard's church.

The most significant indication of this promotion campaign are the pilgrim badges (Sijnte Leonaerts tekenen) that the churchwardens made available to visitors of the Zoutleeuw shrine from March 1478 onwards, i.e. in the very same month as the churchwardens' trip to Brussels after the completion of the altarpiece they had commissioned. 105 The many ways in which these soft metal objects, depicting the shrine's object of veneration, were used, demonstrate the variety of values pilgrims attached to them. Not only were they worn on clothing to publicly express religious feelings, convictions and even social status, they were also kept as amulets or relics that partially carried the thaumaturgic powers of the cult object they represented. It was for this reason that they were sewn into devotional manuscripts or cast onto church bells. ${ }^{106}$ At Zoutleeuw, for instance, pilgrim badges depicting Saints Leonard, Cornelius (from Kornelimünster) and Anne (from Düren) were cast onto the seven bells produced by Medardus Waghevens from Mechelen, in 1530-1531. ${ }^{107}$ Thus, such badges not only functioned as souvenirs of completed pilgrimages, but also as instruments of both private and public devotion.

Pilgrim badges strongly reflect the ambitions of the issuing shrine. The fact that they were worn on clothing means that they were highly visible markers of the cult that could spread its name 
and fame throughout a wider region. As a result, they were preeminent promotional tools, but scholars have demonstrated that churches did not always possess the monopoly on their sale. In several towns they were commissioned by the civic authorities or sold by independent merchants. ${ }^{108}$ Despite the lack of such evidence for Zoutleeuw, several arguments make clear that even if they were no new phenomenon in 1478 , then at least the churchwardens took measures to control and regulate their production, sale and dispersion at that important moment. Soon after the badges first appear in the accounts in 1478, they are referred to on a yearly basis and the following years show a steady development of the supply, suggesting that the practice was in its early stages. A year after the purchase of the first badges from local goldsmith Bartholomeeus vander Moelen (act. 1469, d. 1490-1491), in March 1479 the Leuven sculptor Joes Beyaert (c. 1405-1483) was paid for the making of 'a mold in which one casts Saint Leonard's badges'. ${ }^{109}$ In the earliest years after the acquisition of the mold the accounts do not refer to the casting itself, but they do include entries recording the purchase of tin to make the badges. This suggests that the churchwardens cast the pewter badges themselves at first, while buying the badges in precious metal from the goldsmith. ${ }^{110}$ From 1491 onwards, however, the casting was outsourced to professional tincasters (canghietere), both in Diest and Sint-Truiden. ${ }^{111}$ Certainly from the earliest years of the sixteenth century onwards, the badges were demonstrably available in many different forms and materials, corresponding to different price ranges. Some were made in tinplate, others in copper, silver or gold, and some were supplied with a red paper underneath. ${ }^{112}$

So far, not a single example has been identified with certainty as coming from Zoutleeuw. It has already been proposed that several badges, found in Bruges, Nieuwlande, Rotterdam and The Hague, depicting Saint Leonard and as yet unrelated to any other shrine devoted to him, might have come from Zoutleeuw. ${ }^{113}$ Although this remains hypothetical, the fact that the Nieuwlande badges lack the elements characteristic of the examples issued by other shrines such as Dudzele and Saint-Léonard-de-Noblat, as well as stylistic resemblances between the figure of Saint Leonard as depicted on the badges and Joes Beyaert's monumental sculpture suggest that the two badges from Nieuwlande might have been cast from Beyaerts' mold (fig. 30). ${ }^{114}$

The evidence at hand furthermore clearly shows that the badges were available in steadily increasing quantities from the middle of 


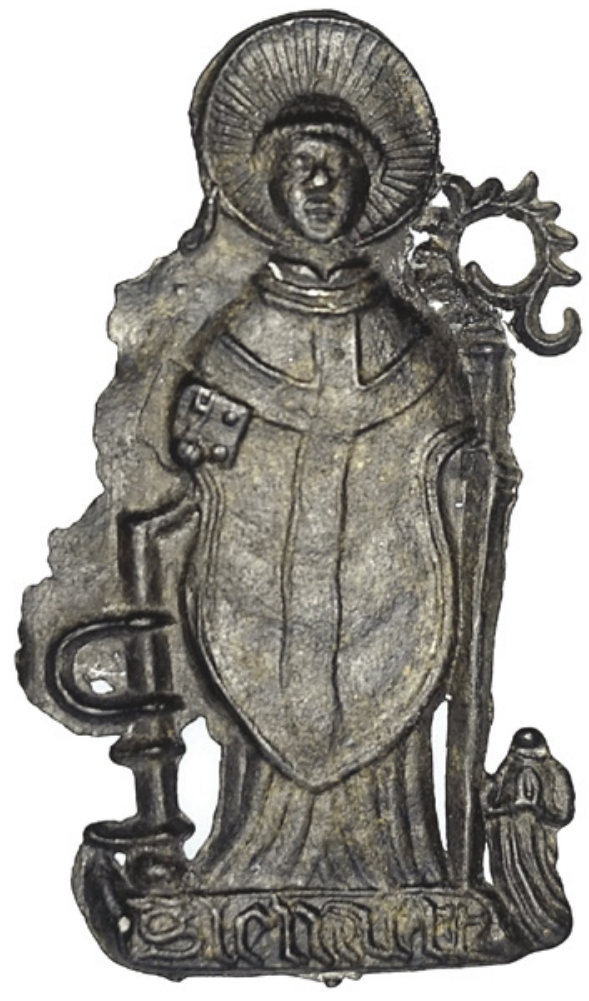

FIGURE 30

Pilgrim badge depicting Saint Leonard, found in Nieuwlande, possibly from Zoutleeuw, c. 1450-150o, Langbroek, Van Beuningen Family Collection PHOTO: WILLY PIRON

the 149 os onwards. Whereas 312 badges were recorded in 1492, this number rose to 768 in 1495 and to $115^{2}$ in 1497 (graph 5). A similar, steady rise is apparent in the budget allotted to this purpose (graph 6). Oddly, contrary to other shrines in the region such as Wezemaal, the Zoutleeuw accounts never record the number of badges that were sold. ${ }^{115}$ This either means that they were handed out freely to pilgrims or more likely, only to those who made an offering, or that the sale of the paraphernalia was subcontracted to stallholders. ${ }^{116}$ From 1482 onwards the fabrica ecclesiae did receive payments for stallage in the church portal (parvise or provijs) next to the chapel and the churchwardens' room (figs. 4 \& 25 , compare with fig. 31). Some of the tenants were merely described as peddlers (cremer), but others were described as jewelers, and it is not inconceivable that they sold such badges. ${ }^{117}$ In any case, whether the badges were actually sold by these stallholders or not, the fact that they are mentioned points to an increasing diversity of activities in and around the church building, which was presumably caused by a rising number of pilgrims coming to town. 


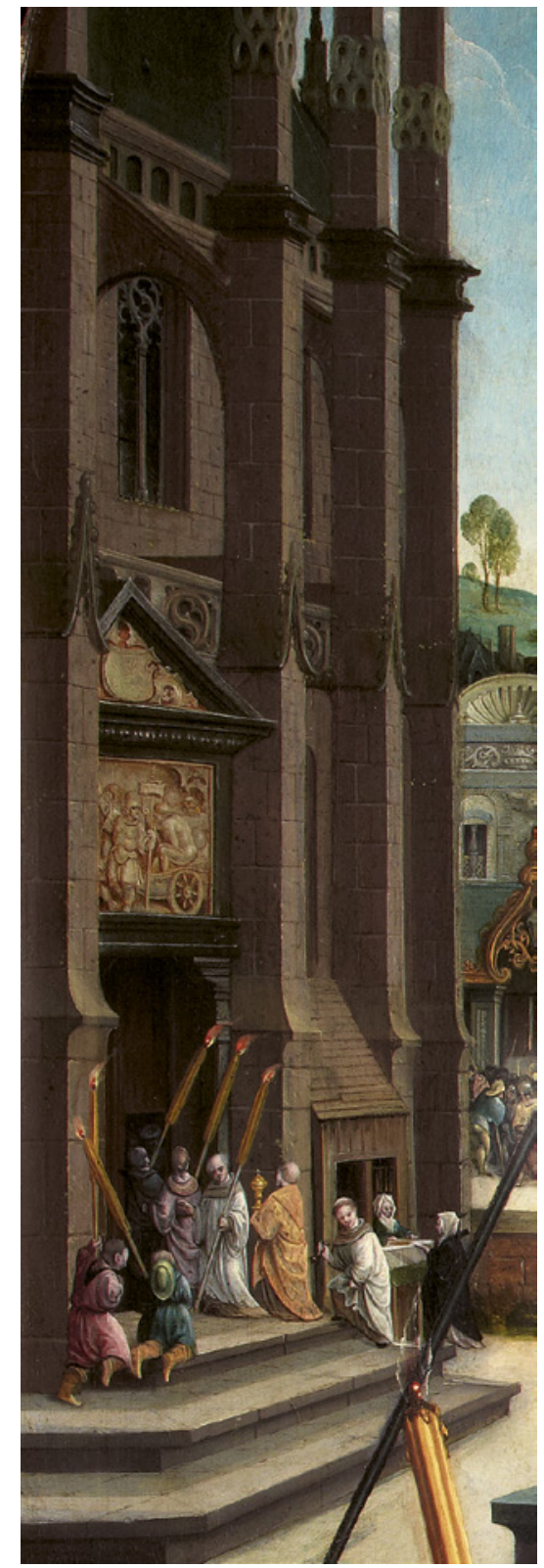

FIGURE 31

Jan Provoost, Scenes from the legends of St Anthony of Padua and St Bonaventure, detail, 1521, Brussels, Royal Museums of Fine Arts of Belgium (C) RMFAB, BRUSSELS / PHOTO: F. MAES

A second indication of the churchwardens' promotion of the cult of Saint Leonard is the acquisition of a papal indulgence bull. In April 1485 the accounts record the payment of four Rijnsgulden 'for the indulgence bull sent from Rome.'118 The document itself has not been preserved and its contents are unknown, but it is not 
unreasonable to assume that the fabrica ecclesiae, with or without the support of the collegiate chapter, had petitioned an indulgence bull related to the statue of Saint Leonard that had worked a miracle one year prior. ${ }^{119}$ Most of the papal bulls - including indulgences were in fact not issued on the initiative of the Pope himself, but only after a supplication was submitted to the Apostolic Chancery by the petitioning party. In case the request was granted, the administration drew up the official bull, the text of which often followed closely that of the supplication, which was then sent to the requesting party. ${ }^{120}$ Upon arrival, the obtained privileges were soon proclaimed by means of various media, whereby larger churches such as cathedrals or collegiate churches evidently had more means at their disposal than smaller parish churches. ${ }^{121}$ The indulgence letters were often lavishly illuminated by renowned painters and hung in public places such as church doors or city gates. Other churches, such as Antwerp's church of Our Lady, went further than merely advertising within the church or town, and paid for the sending out of copies or priests to preach the indulgence. ${ }^{122}$ These media campaigns are not surprising, as it goes without saying that such indulgences made a shrine much more attractive to potential pilgrims. It was therefore of primary importance to spread the information as soon and as far as possible. ${ }^{123}$ Given the important financial potential indulgences had, their role and significance in relation to the financing of church construction have been amply emphasized elsewhere, and, as will be argued below, a similar rationale might have been at play in Zoutleeuw. ${ }^{124}$

\section{Furnishing Sacred Space: Saint Leonard's Chapel}

The introduction of pilgrim badges and the procurement of the indulgence illustrate that the churchwardens used a variety of methods to spread the word about Saint Leonard's cult in order to firmly establish it. In this respect, the chronological coincidence with the commissioning of Saint Leonard's altarpiece is not accidental. Scholars have indeed argued that the architecture of churches and the art in their interiors played a key role in advertising devotions, as elaborate and ingenious artworks attracted people into the churches. ${ }^{125}$ In Zoutleeuw, too, this seems to have been used as promotion strategy. In fact, the enormously increasing expenditures for interior decoration between 1476 and 1483 indicate that the church underwent a major decoration campaign in precisely this period, thus coinciding with the subtly increasing revenues and immediately preceding 
the 1483 peak (graph 7). Although the whole church benefited from this campaign, Saint Leonard's chapel was clearly given a prime role, suggesting that it was part of a preconceived plan. The decoration campaign commenced with the commission of the altarpiece in 1476 and in subsequent years the sacred space would be fully provided with lavish ornaments suited to venerating the liberating saint in an appropriate way. The room's 1820 reorganization into a sacristy, the altar's replacement into the southern transept and the subsequent sale of various decorative elements it originally contained have turned it into one of the lesser preserved parts of the church, but a comparative analysis of the churchwarden accounts allows for a reconstruction of its interior to a sufficient degree.

In February 1478, a month before the new altarpiece was delivered, Arnold de Raet was paid for making paintings (molerijden) in the chapel. ${ }^{126}$ Immediately before a scaffolding had been bought 'for making Saint Leonard's work', suggesting that De Raet decorated the walls of the chapel with figurative or ornamental mural paintings, comparable to those that have been preserved in the southern transept, above and directly next to the entrance to the chapel (figs. 32 \& 33). ${ }^{127}$ These are doubtless contemporary and although they are not documented, they might have been executed by De Raet as well. ${ }^{128}$ Later, in June 1481, 'a new casse in which Saint Leonard will stand' was commissioned from the sculptor Joes Beyaert. ${ }^{129}$ The word casse was used in a broad sense to designate a shrine holding objects of veneration. Given the description provided in the entry in the accounts, and considering that Beyaert was known to be a sculptor of wood and stone, it is safe to assume that it must have been a wooden tabernacle or niche crowned with a carved ornamental baldachin in which the venerated statue of Saint Leonard was placed. Such tabernacles, which mostly could be closed with painted wings, are standard features in contemporary descriptions and depictions of church interiors (fig. 34). ${ }^{130}$ Until a theft in 1983 the Zoutleeuw church itself preserved an example that probably belonged to the altar of Saint Anne (figs. 35 \& 36). ${ }^{131}$ Saint Leonard's tabernacle has not been preserved, but it is depicted as having wings on the 1612 painting commemorating a miraculous healing (fig. 128). Once again the help of Arnold de Raet was called in by the churchwardens to redecorate Saint Leonard's sculpture with paint in 1481, as well as its new tabernacle in $1482 .{ }^{132}$ Still in 1482 an antependium was bought for 18 Rijnsgulden from the embroiderer Anthonis Jonckeren from Lier, 'to hang before Saint Leonard's altar on feast and 

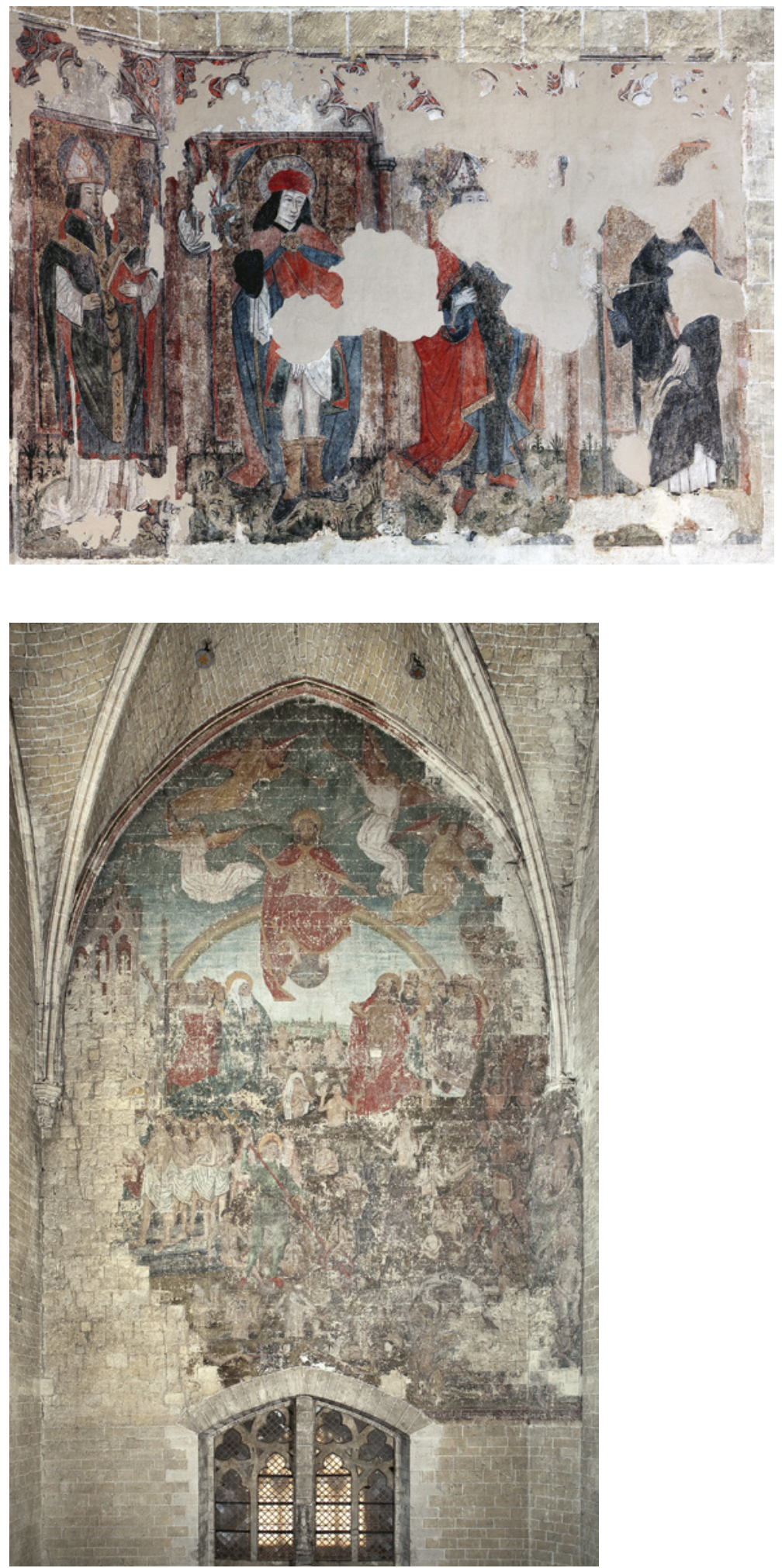

FIGURE 32

Anonymous (possibly Arnold de Raet), Saints Servatius, Roch, Albert and Giles, c. 1480-150o, Zoutleeuw, church of Saint Leonard (C) KIK-IRPA, BRUSSELS

FIGURE 33

Anonymous (possibly Arnold de Raet), Last Judgment, c. 1480-1500, Zoutleeuw, church of Saint Leonard

(C) KIK-IRPA, BRUSSELS 


\section{FIGURE 34}

Master of Saint Augustine, Scenes from the life of Saint Augustine of Hippo, detail, c. 149o, New York, Metropolitan Museum of Art

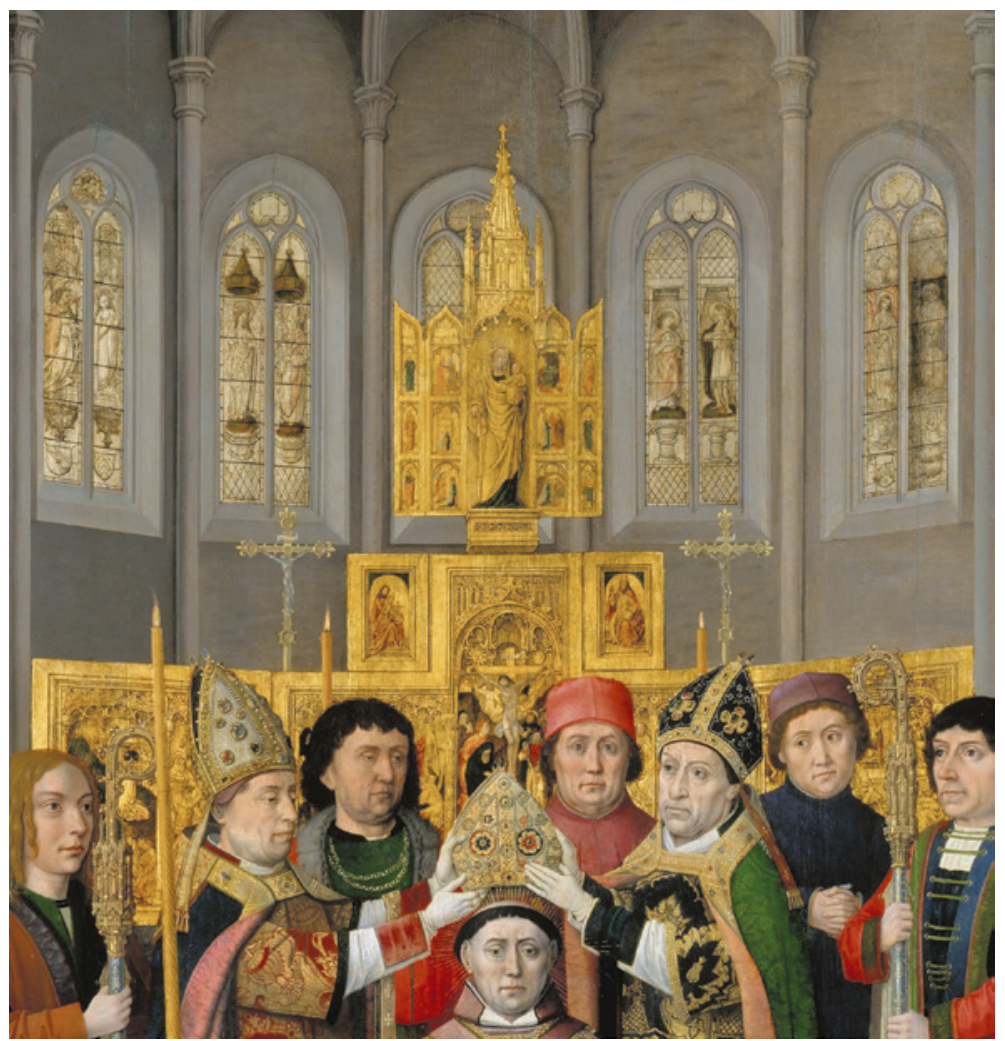

holy days.' ${ }^{133}$ Finally, in the same year, a complex brass candelabrum (luymenarys, later also kendelere) was commissioned for the chapel from the Brussels caster Renier van Thienen (act. 1465-1498). ${ }^{134}$ The agreement stipulated that it should be made 'in the manner of that in the church of Saint Gudula in Brussels'. Arnold de Raet was again involved in the design, as he was paid for making a pattern (patroen) and accompanying the churchwardens to Brussels for the commission. It was installed in the course of $1483 .{ }^{135}$ This candelabrum was sold early in the nineteenth century after a Royal Decree of 1827 had permitted the sale of 'old copper'. As a result it has disappeared completely, save for a 56 centimeter high statuette of Saint Leonard that according to Bets was once part of it and which is now kept in Rotterdam (fig. 37). ${ }^{136}$

Apart from the wooden statue of Saint Leonard, the altarpiece and some scattered traces of the candelabrum, nothing has been preserved. Although the former has been placed in the middle of the altarpiece since at least the nineteenth century, it must originally 

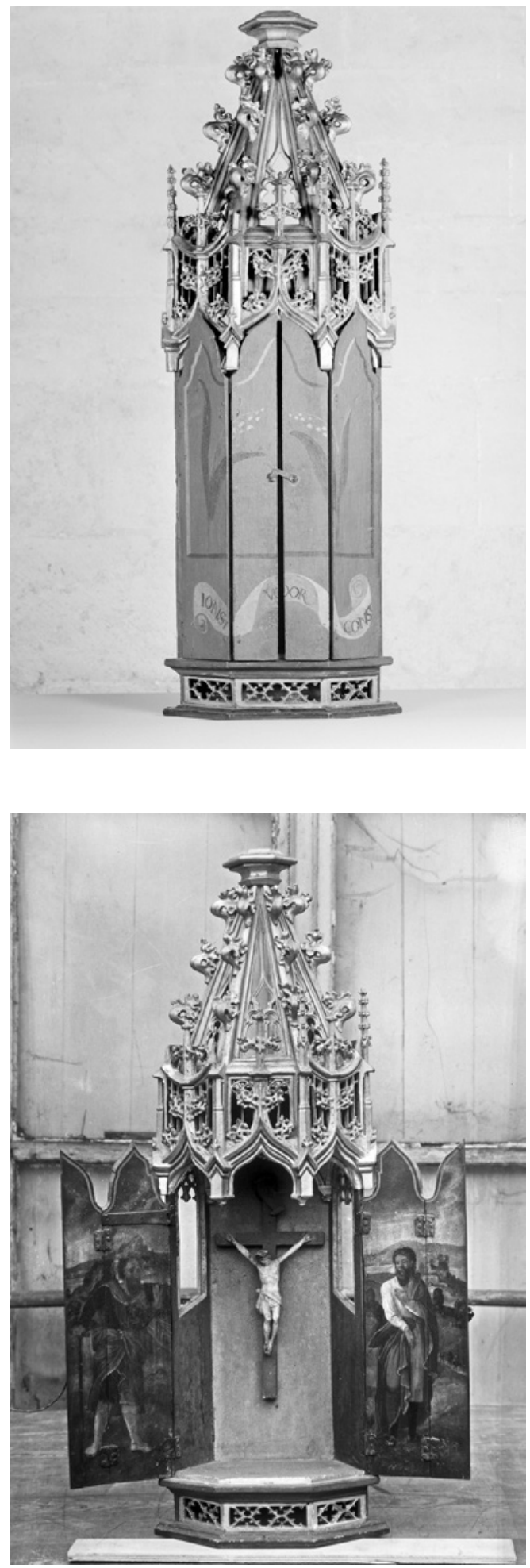

FIGURE 35

Anonymous, Tabernacle of Saint Anne, closed, c. 1490-1510, originally Zoutleeuw, church of Saint Leonard, stolen in 1983

(C) KIK-IRPA, BRUSSELS

\section{FIGURE 36}

Anonymous, Tabernacle of Saint Anne, open, c. $1490-1510$, originally Zoutleeuw, church of Saint Leonard, stolen in 1983 (C) KIK-IRPA, BRUSSELS 


\section{FIGURE 37}

Renier van Thienen,

Saint Leonard, 1482-1483, Rotterdam, Museum

Boijmans-van Beuningen

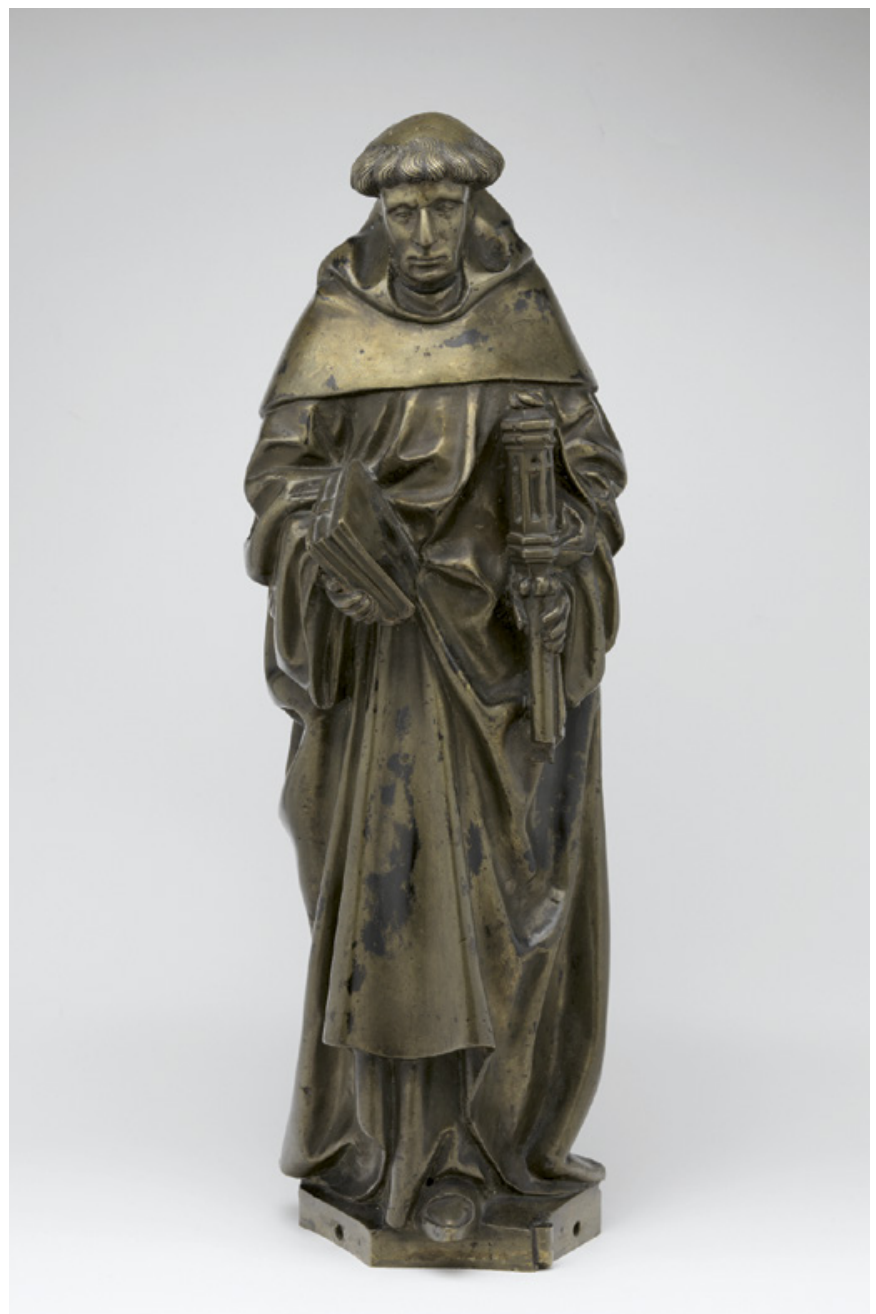

have been exhibited in the tabernacle carved by Beyaert and polychromed by De Raet. The 1612 painting - the only iconographical source depicting the interior of the chapel - indeed locates the statue in a tabernacle standing on an altar provided with altar cloth and liturgical utensils (fig. 128). This tabernacle, in turn, must have been placed on top of the altarpiece. Several entries in the Zoutleeuw accounts indeed evoke the cult object's high placement, and contemporary depictions of church interiors regularly show statues on top of altarpieces, either or not enclosed in a tabernacle (fig. 34). ${ }^{137} \mathrm{~A}$ 1522 depiction of the miraculous healing of a child by Saint Stephen in Korbeek-Dijle shows precisely such a spatial arrangement: the 


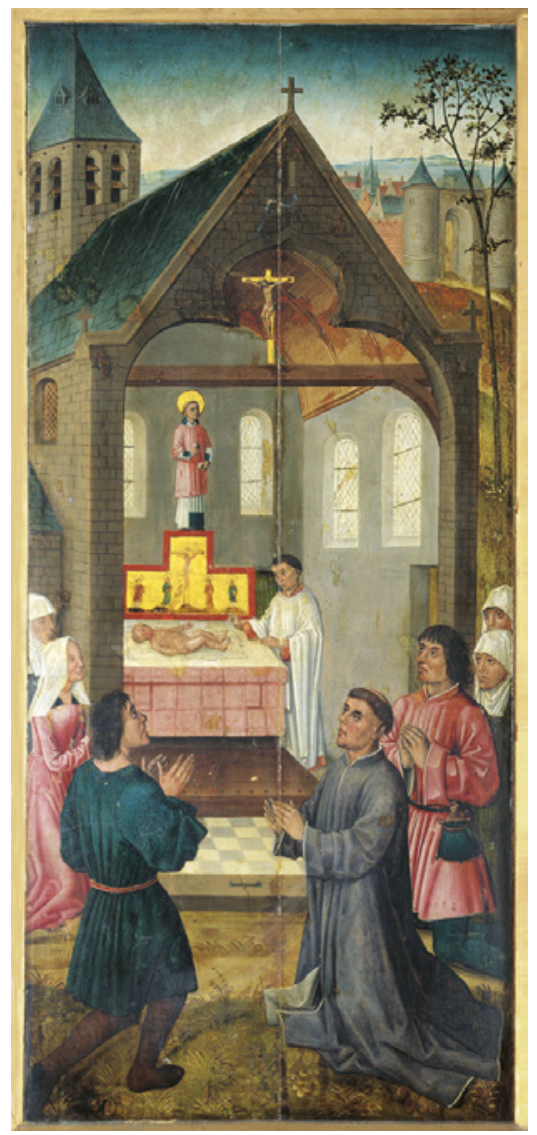

FIGURE 38

Jan vander Coutheren, The healing of a child by Saint Stephen, from the outer wings of the altarpiece of Saint Stephen, 1522, Korbeek-Dijle, church of Saint Bartholomew PHOTO: JOHAN GELEYNS - RO SCAN

altar on which the child lies is provided with an altarpiece in inverted T-shape, on top of which stands the invoked image of Saint Stephen (fig. 38). ${ }^{138}$ The 1612 Zoutleeuw painting omits the altarpiece, but its absence can be explained as a simplification on the part of the painter, presumably for the sake of clarity.

The original outlook of Renier van Thienen's complex candelabrum can also be reconstructed, although the structure in the Brussels church of Saints Michael and Gudula to which the financial agreement referred has not been preserved. The terms used - luminaris or candelare - are vocabulary that generally designate candleholders in a broad sense. The preserved Easter candlestand that was commissioned from Van Thienen soon afterwards, for instance, was alternately referred to by one of these terms (fig. 39). ${ }^{139}$ Nevertheless, it must have looked quite different, and the evidence at hand in fact suggests that it was an elaborate arched candelabrum standing in 
FIGURE 39

Renier van Thienen,

Easter candlestand, 1483,

Zoutleeuw, church of Saint Leonard

(C) KIK-IRPA, BRUSSELS

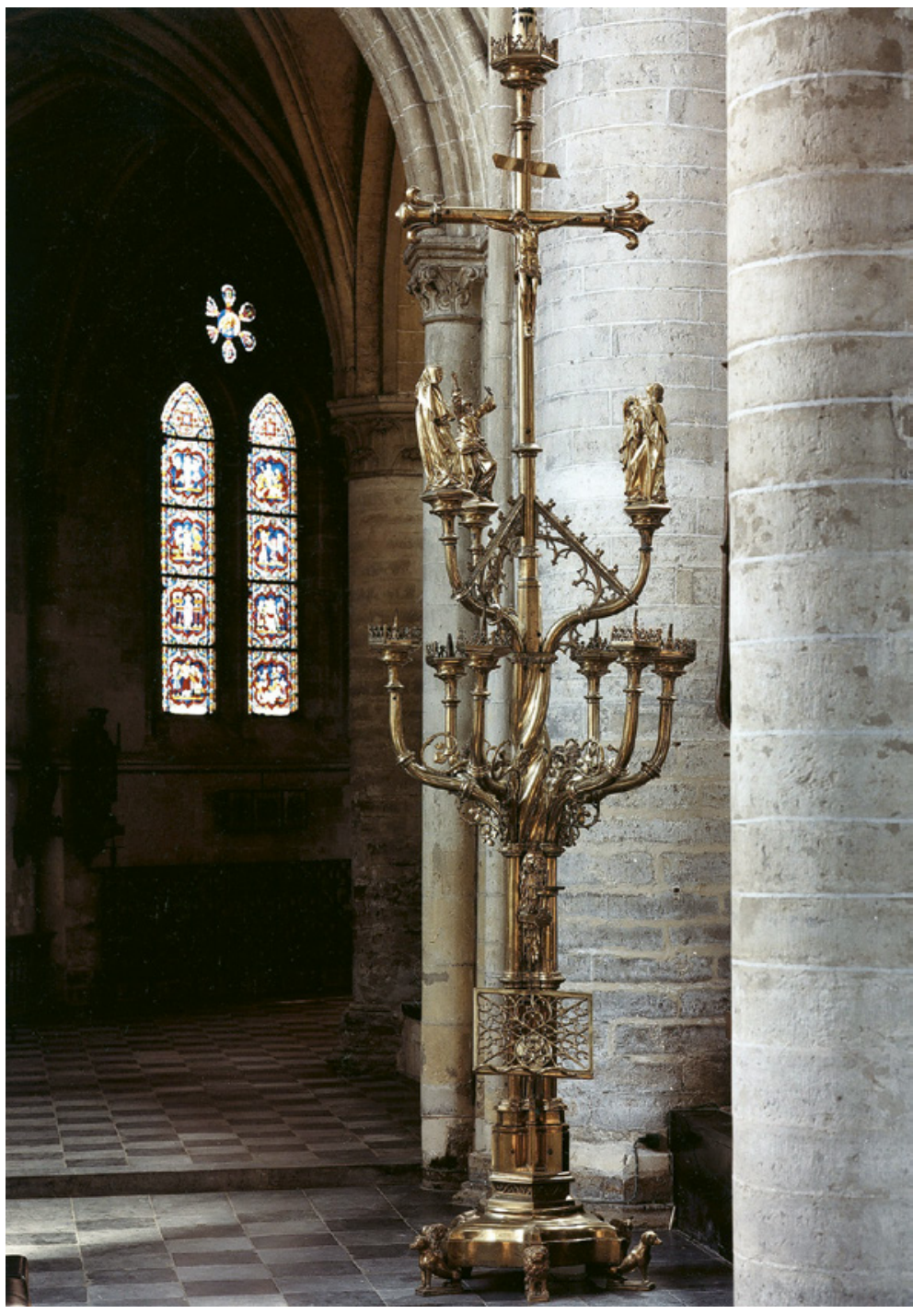

front of the altar. An entry in the accounts related to the acquisition and installation mentions the payment of 'two blue stones on which the posts with the angels stand', and later workmen are paid 'to cut the feet on which the candelabrum stands.'140 Both entries likely refer to two hexagonal bluestone socles that are still preserved in the church, which in turn correspond to a hexagonal hole in the chapel floor (figs. 40 \& 41). No contemporary descriptions or depictions of the work are known, but a church inventory predating the 


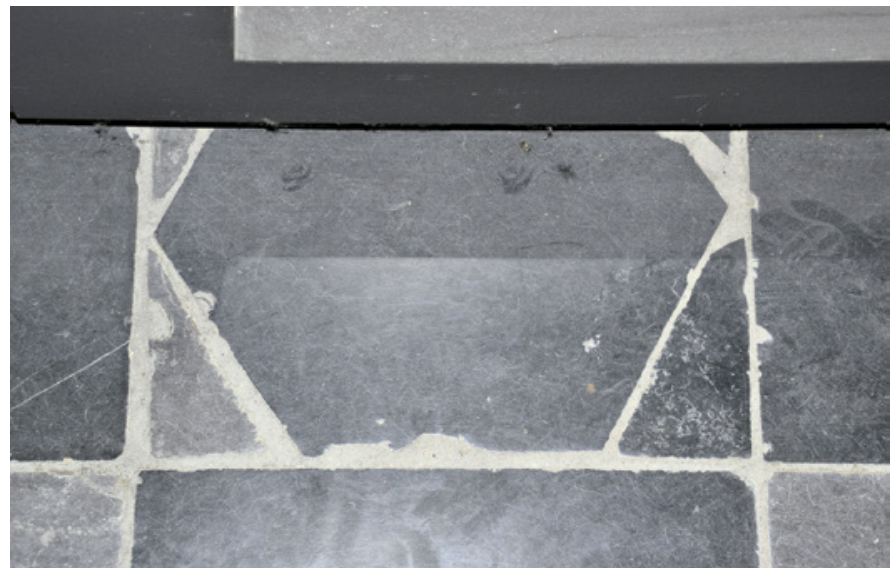

FIGURE 40 Hexagonal cut-away in the floortiles of Saint Leonard's chapel, Zoutleeuw, church of Saint Leonard PHOTO: AUTHOR

1827 decree provides valuable further information. In the chapel of Saint Leonard it mentions 'two brass pillars, on top of which stands a brass angel. The one with the cross in its hands lacks a wing'. It also describes an arch (loop) 'as broad as the chapel is, with elaborate work.' ${ }^{141}$ This means that the candelabrum integrated the traditional altar angels, which were a standard feature in church interiors, as evidenced by contemporary depictions (fig. 42). Traditionally, such angels stood on pillars in front and/or on the side of the altar and were usually used to hold up curtains that hung at both sides. Few examples have survived, but they are frequently documented all over the fifteenth- and sixteenth-century Low Countries and some rare sets have been preserved (figs. 43 \& 44). ${ }^{142}$ In Zoutleeuw they were integrated into a more encompassing candelabrum spanning the breadth of the chapel that doubtlessly gave central place to the brass statuette now in Rotterdam. It can therefore be assumed to have been similar to the example still preserved in Xanten, dating to 1501 (fig. 45). ${ }^{143}$ Though this example features figures of saints on the pillars, other examples integrating the altar angels are known, such as the structure that was donated to the abbey church of Gembloux in 1515 by abbot Mathieu Petri (r. 1511-1517) (figs. 46). ${ }^{144}$

All these elements enable us to reconstruct the chapel with a high degree of accuracy (fig. 47): it included an altarpiece with an inverted T-shape, crowned with the statue of Saint Leonard in a

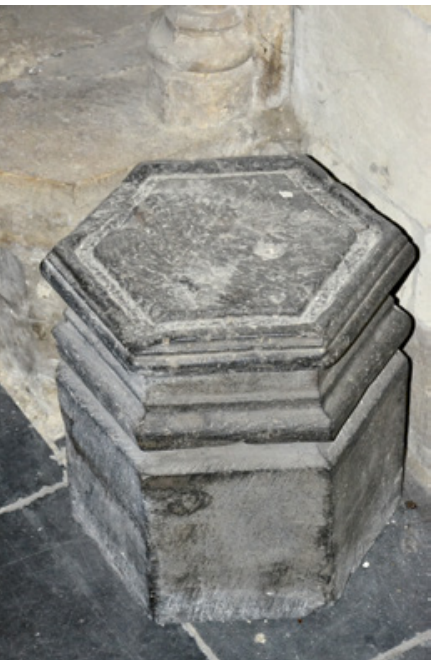

FIGURE 41

Hexagonal bluestone socle, 1483, Zoutleeuw, church of Saint Leonard PHOTO: AUTHOR 


\section{FIGURE 42}

Master of Saint Godelieve, Altarpiece depicting scenes from the life of Saint

Godelieve, detail of the center panel, c. $1475^{-1500,}$ New York, Metropolitan Museum of Art

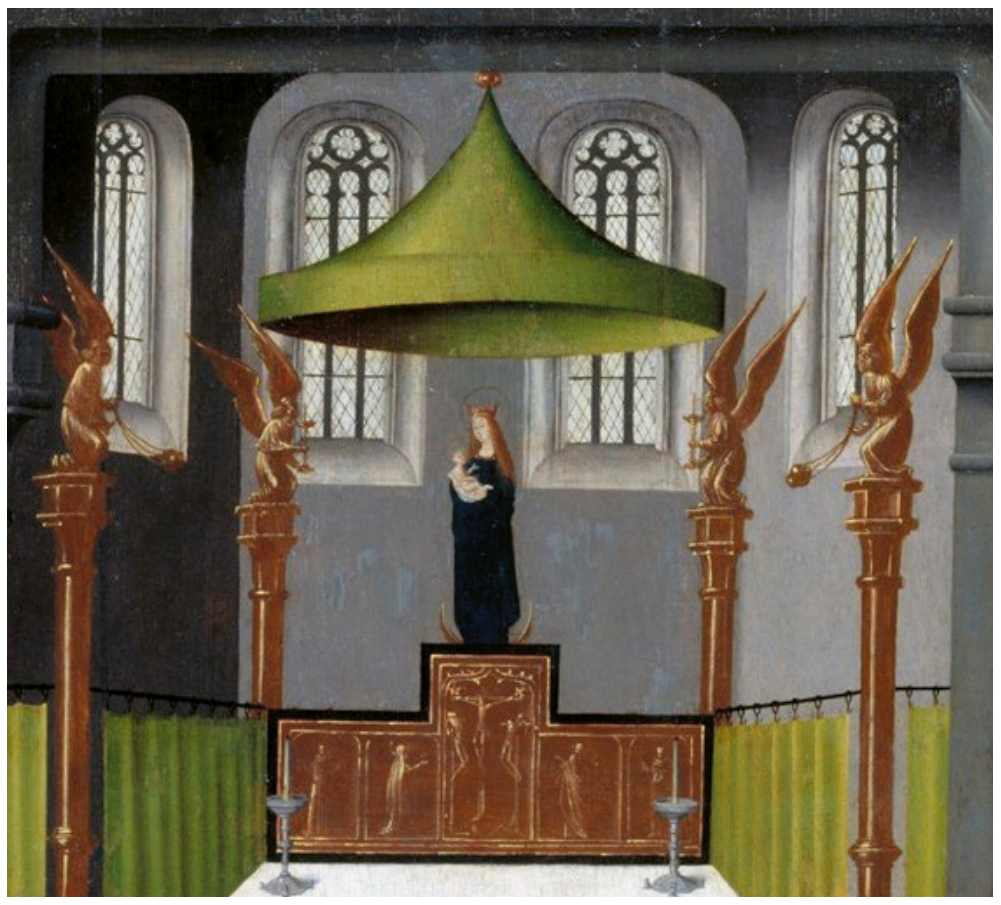

tabernacle and flanked by brass altar angels that served as candleholders, and the entire space was lit by a window from the back. However, the precise location and orientation of the altar remains as yet untouched. Traditionally, medieval altars are supposed to be oriented towards the east - like the presbytery in Zoutleeuw - but the reconstruction of the location of the monumental candlestand in the chapel suggests that Saint Leonard's altar did not face east, but south. ${ }^{145}$ The only remaining traces of the brass construction are the two hexagonal socles in bluestone and one corresponding hexagonal hole in a tile in the southwestern corner of the chapel floor (figs. 40 \& 41). The hole for the second socle is now lost but was located to the east of the hole that is still preserved, implying that the candlestand followed an east-west axis (compare with fig. 4). ${ }^{146}$ Similar examples are known to stand before the altar and run parallel to the long frontal side of the altar stone.

This would suggest that in this particular case the altar itself was oriented southward. Any other alternative option based on the location of the preserved tile would not only have been liturgically inconvenient for the celebration and attending of Masses, but would also have gravely diminished the desired effect of the lighted candles 


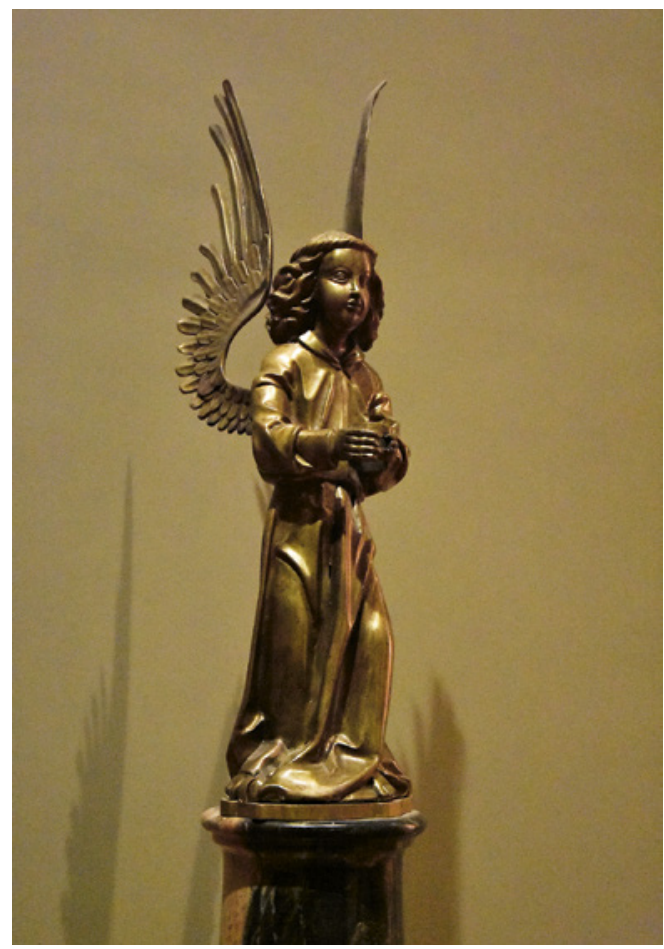

FIGURE 43

Anonymous, Altar angel, late fifteenth century,

Paris, Louvre

PHOTO: AUTHOR

on it. Surveys of the orientation of churches in English, German and Italian territories have demonstrated that the importance of the tradition of 'easting' diminished from the fifteenth century onwards, but no comparable overviews for the Low Countries exist. ${ }^{147}$ Contemporary visual sources nevertheless confirm that the idea of altars with an orientation perpendicular to that of the main altar was not inconceivable. ${ }^{148}$ It seems plausible, furthermore, that the orientation of churches as well as the altars within them and in later added structures in part was dictated by practical grounds. The choirs of the Brabantine abbey churches of both Rooklooster (1381-1384) and Groenendaal (1512), for instance, were oriented to the south, and that was also the case in the old, thirteenth-century church of Our Lady in Laken. ${ }^{149}$ These churches are all located in the surroundings of Brussels, and their orientations seem to have been due to the highly irregular landscape that characterizes the region. Similarly, the southward orientation of Saint Leonard's altar in Zoutleeuw likely was the consequence of the fact that an ancient portal - with stone pews integrated in both its eastern and western walls - was transformed into a chapel. 


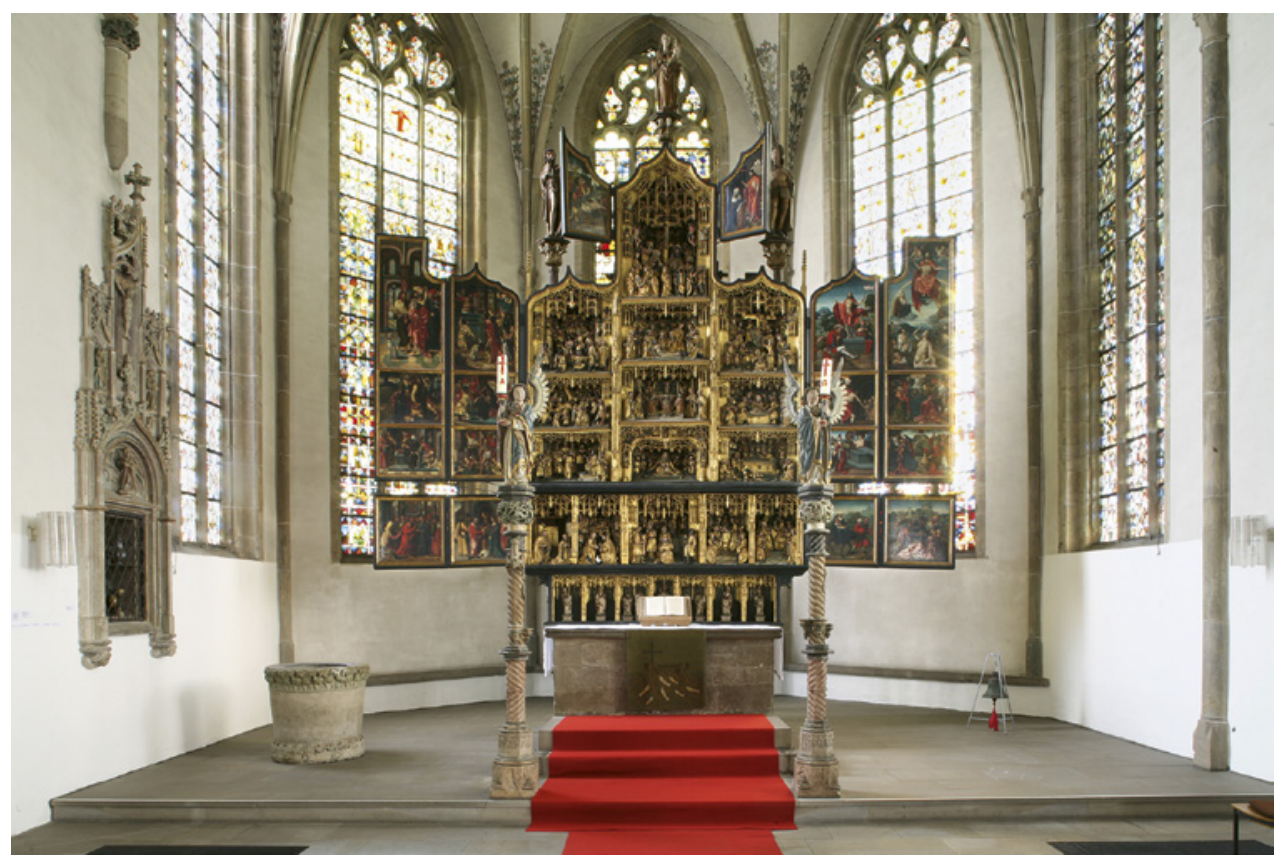

FIGURE 44 Altar angels flanking the high altar, Schwerte, Sankt Viktor PHOTO: JUSTIN KROESEN

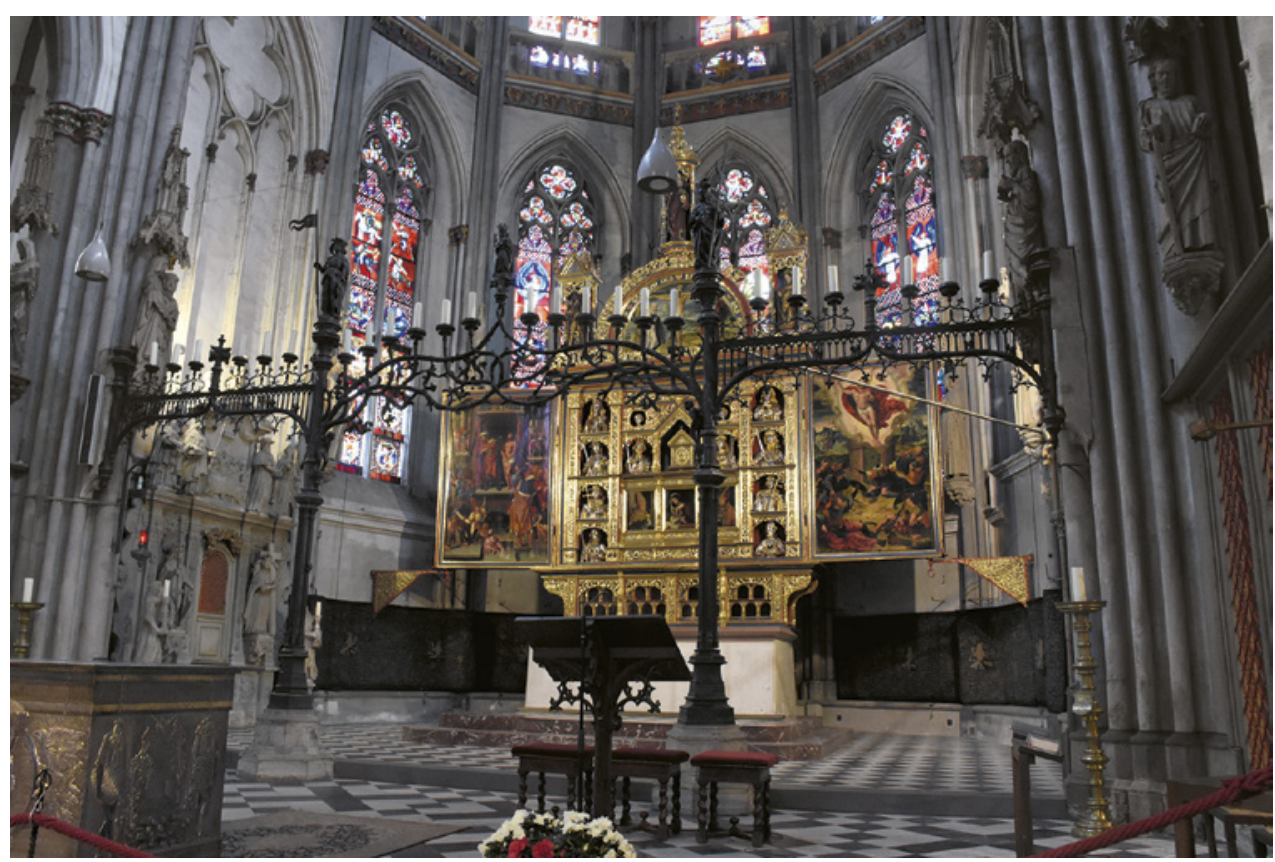

FIGURE 45 Aert van Tricht, Arched candelabrum, 1501, Xanten, Sankt Viktor PHOTO: ELIZABETH MATTISON 


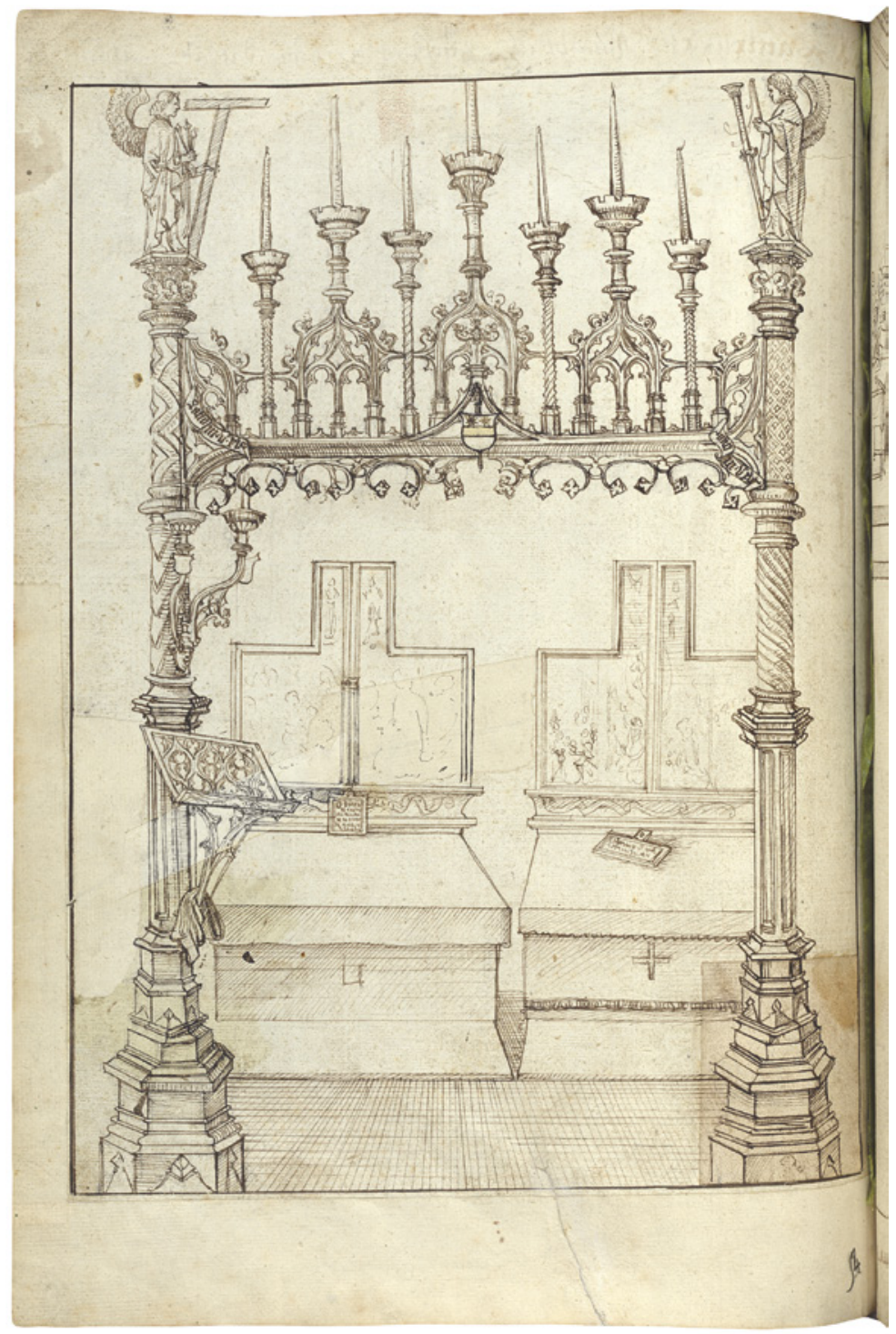

\section{Creating Sacred Space: Making It Work}

The question remains, how should all these actions on the part of the churchwardens be assessed? Was it a reaction to the increasing popularity of Zoutleeuw as devotional destination, or was it a proactive strategy to attract potential pilgrims? While the revenues from monetary offerings increased subtly in preceding years, this certainly does not provide a conclusive answer. All the references to a broader devotional attention postdate the first stages of the decoration campaign: the first specific references to pilgrims in the accounts date to
FIGURE 46

Antoine Papin, Candelabrum donated by Abbot Mathieu Petri in 1515 to the abbey church of Gembloux, 1527-1528, from the Gesta abbatum Gemblacensum, Brussels, KBR, Ms. 10292-94, fol. $71 \mathrm{~V}$ 


\section{FIGURE 47}

Interior view of Saint

Leonard's chapel,

axionometric reconstruction

DRAWING: JACQUES TOUSSAT

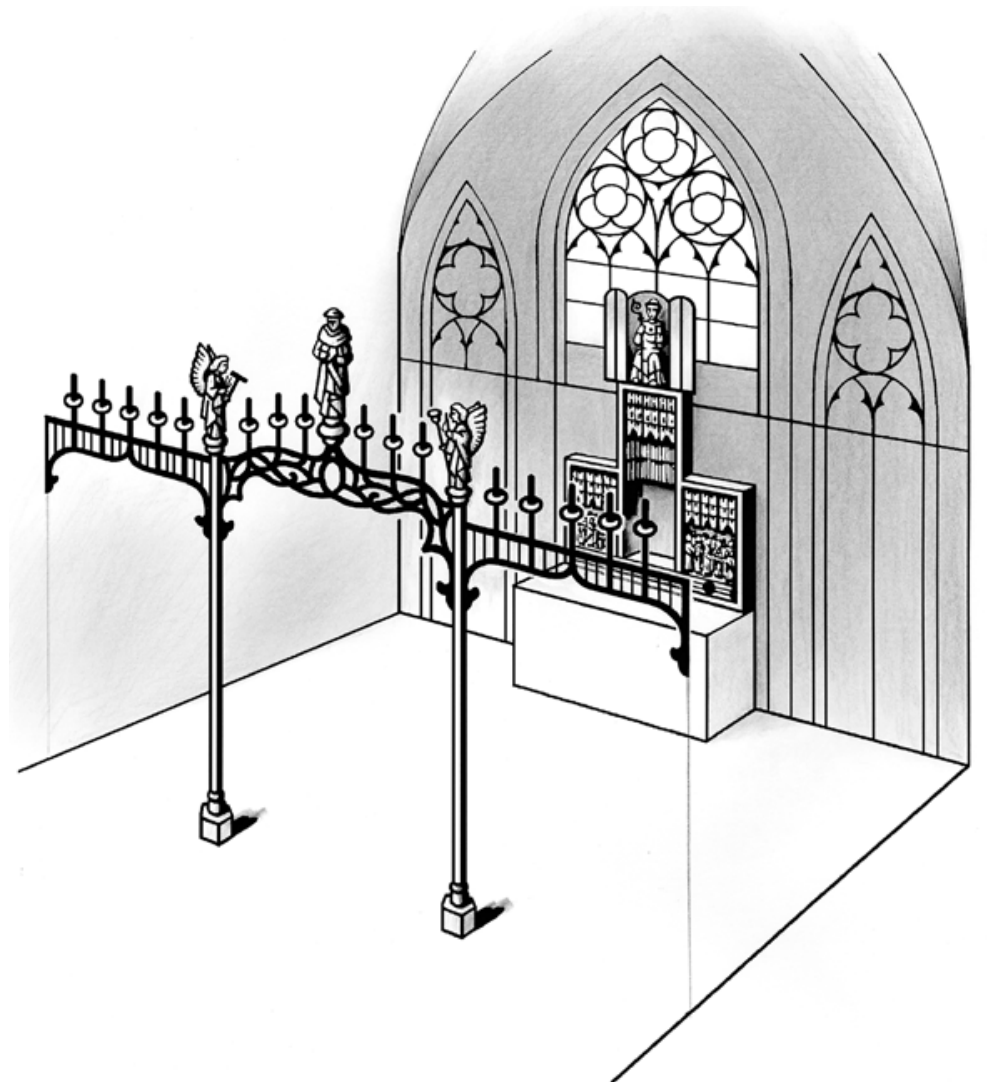

1480, the first incontestable evidence of a miracle to 1484, and the first distribution of bread to pilgrims to 1490 . A closer look at the financing of the whole campaign provides clearer answers. While furnishing activities were often partially or fully funded by private investments, no such funding is documented for Saint Leonard's chapel, apart from the modest 2,5 Rijnsgulden donated by the dean of the chapter. ${ }^{150}$ Confraternities also served as important patrons for the decorations of their chapels, but the only documented organization of the kind in Zoutleeuw was the arquebusiers' guild devoted to Saint Leonard, which was only erected in 1515 and thus cannot have contributed to the furnishing of the chapel. Although the revenues from monetary offerings became proportionally increasingly important in comparison to the fixed revenues, neither of them were sufficient to fully cover the expenses. And yet, it was clearly not a reckless investment on the part of the churchwardens, since the extraordinary revenues were always sufficient (graph 8). In fact, it appears that in precisely these years significantly more corn 
was sold from the fabrica ecclesiae's stock, with notable peaks in 1476 and 1478 - not coincidentally the first years of the decoration campaign (graph 9). Since it is very unlikely that in precisely these years the wardens collected more than two to four times more corn than during other years, this pattern most likely points to a controlled and specific sale of surplus from the granaries. This, in turn, suggests a well-planned action.

Churchwardens played an essential role in promoting and developing cults. Research has often linked this to building campaigns, showing that in several cases the numbers and proportions of gifts to churches were, to a considerable extent, connected to the construction of the building in question. For instance, Gerrit Verhoeven has suggested that the churchwardens in Delft actively sought to stimulate devotions when fundraising for new construction projects. ${ }^{151}$ In principle, a similar line of argument might be applicable in Zoutleeuw as well. By the second half of the fifteenth century the basic structure of the church building - including the choir, the transept and the western part - were erected, but it was far from finished nor fully decorated. The wooden vaulting of the nave would only be replaced by the current brick one from 1503 onwards, and the side chapels on the southern side of the church were constructed later still, between 1507 and 1511 . All these constructions were overseen by Jan I and II Sallaken. ${ }^{152}$ The northern side chapels would follow in 1520. Even so, we can deduce from the fact that multiple altarpieces were bought prior to this time, that the decoration of the rest of the church had started even earlier. Initially Joes Beyaert received most of these commissions, but after his death in 1483 the churchwardens turned increasingly to Jan Mertens (act. 1473-c. 1509) from Antwerp with whom they had already worked before for other sculptural works. ${ }^{153}$ The list includes the altarpieces for the high altar and for the altar of Saint Catherine (fig. 48), which were both paid for in $1479,{ }^{154}$ the altarpieces for the altars of Saint John the Evangelist and Saint Nicholas commissioned in June 1481, ${ }^{155}$ three other unspecified altarpieces early in $1483,{ }^{156}$ the altarpiece of Saint John the Baptist in March 1484, ${ }^{157}$ and the altarpieces of the Saint Christopher, Saint George (fig. 49), the Holy Trinity, Saint Anthony and Saint Cornelius in March 1485. ${ }^{158}$

Among all these works, Saint Leonard's chapel was clearly prioritized. Saint Leonard's altarpiece is very likely the oldest of the church's total collection of eleven altarpieces from the fifteenth and sixteenth centuries. Nine of these are nearly fully preserved, two of them are partially preserved. This is significant because also in the 


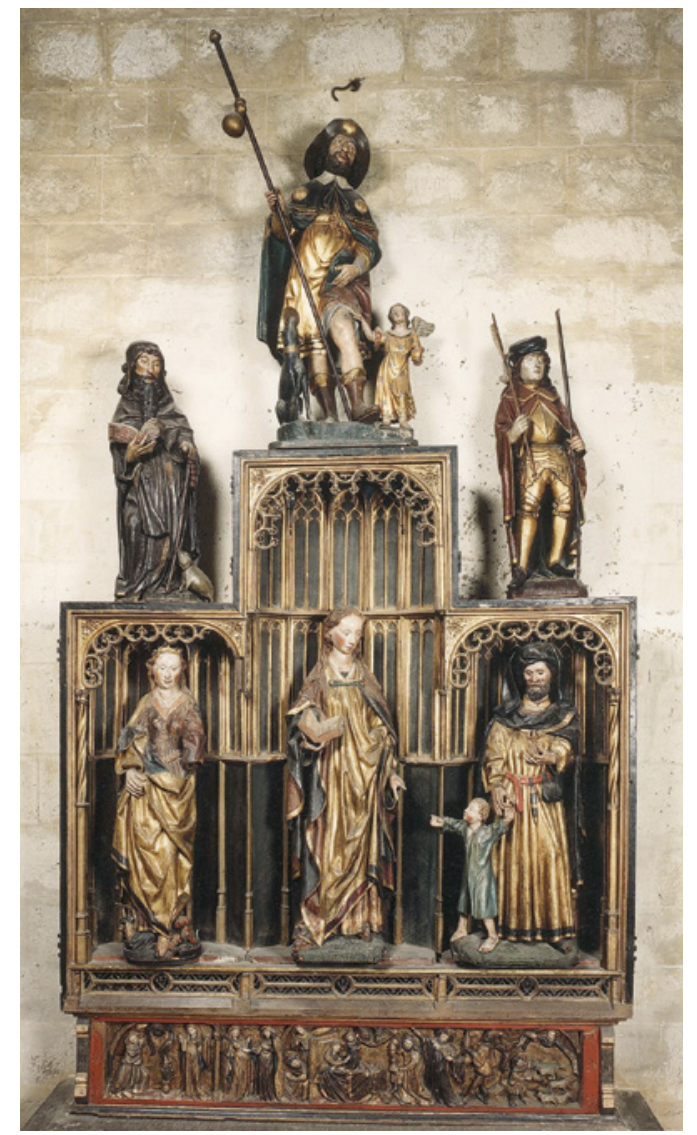

FIGURE 48

Joes Beyaert, Altarpiece of Saint Catherine, 1479, Zoutleeuw, church of Saint Leonard

(C) KIK-IRPA, BRUSSELS

churchwarden accounts it precedes the whole series of commissions that would follow immediately afterwards. This is all the more striking since Saint Leonard's altar had been consecrated in 1442 and had, in fact, already been provided with an altarpiece in 1453. In October of that year a tafele for Saint Leonard's chapel was bought for 16 gripen (16o stuivers), and immediately afterwards the painter Willem van Colene was paid nearly the same amount to polychrome it. ${ }^{159}$ Seen in this light, the sudden campaign in $1476-1483$ to redecorate the chapel seems quite striking: only 23 years later the wardens bought a new altarpiece that would cost nearly 10 times more. In principle, there was no need for a new one. Moreover, other altars in the church, including the high altar, would only be provided with their altarpiece later on. Thus, the decoration of Saint Leonard's chapel in many ways preceded that of the rest of the church. Similarly, the luminaris in Saint Leonard's chapel was commissioned before that in the presbytery (fig. 39). It therefore seems that the cult of 


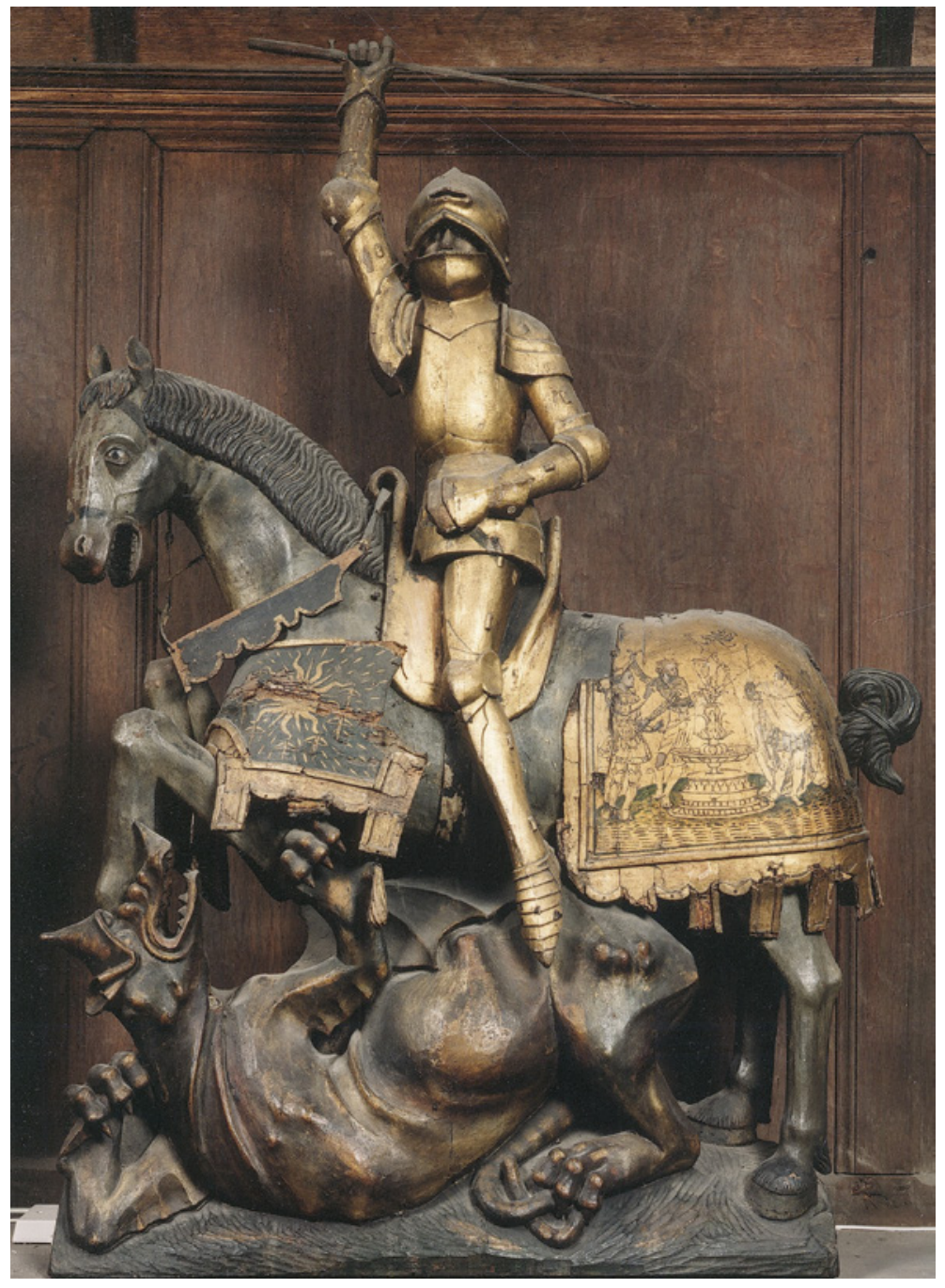

FIGURE 49

Jan Mertens, Saint George, 1485-1486, Zoutleeuw, church of Saint Leonard (C) KIK-IRPA, BRUSSELS

Saint Leonard was given precedence over the traditional, sacramental provisions. ${ }^{160}$

By furnishing the chapel and providing all the necessary accommodation for potential pilgrims, the churchwardens profoundly shaped the cult of Saint Leonard. Although nothing is known about how and where the statue of Saint Leonard was presented before, it is clear that the 1476-1483 decoration campaign foregrounded the statue as the material focus of the saint's veneration in Zoutleeuw. By enhancing its sacred aura it was definitely presented as a cult statue which was worthy of veneration: it was located in its own chapel, separated from the rest of the church, freshly decorated with 
paint and given an emphatic, distinguished and privileged place in an ornamented tabernacle on top of a gilded altarpiece narrating the miraculous story of his life. All this was lighted by an impressive candelabrum, that doubtlessly enhanced the atmosphere by animating the statue. ${ }^{161}$ The statue was thus imbued with 'miraculous charisma', by means of a process described by David Freedberg as enshrinement, i.e. the giving of a prominent place to cult images within a focused context. According to Freedberg the decoration and presentation of cult objects was, in many cases, more important than the image itself, as that 'is what makes these pictures and statues effective, and what attracts the crowds'. Such a strategy proved to be particularly effective in shrines with older images, as was the case in Zoutleeuw. ${ }^{162}$ Other scholars have emphasized the relation between decoration or ornament and the sacred character of objects and places. Kavaler, for instance, has demonstrated how sacred space was essentially created by the gothic ornaments within it and the elaborate vaults that shaped it. ${ }^{163}$ The effectiveness and attractiveness of cult objects were thus closely related: in order to be effective within a circuit of competing shrines, they had to be inviting. ${ }^{164}$ Thaumaturgic cult objects were the reason for people to undertake pilgrimages, i.e. long or short journeys driven by hope and expectation and undertaken in order to receive divine grace. Especially for the ill and handicapped - arguably the largest part of pilgrims ${ }^{165}$ - the bodily experiences of such a journey must have been particularly intense. Consequently, it is not hard to imagine that the distinct setting, atmosphere and presentation of cult objects such as Saint Leonard's statue shaped the religious experience of visitors upon arrival.

In Zoutleeuw, efforts were made to create the optimal conditions for a miraculous experience, and the cult of Saint Leonard was promoted in a wider region. But the motivations behind these initiatives remain to be established. Can a purely financial desire explain these investments and actions? Circumstantial evidence suggests that the cult did not immediately provide a substantial surplus of revenues that was able to cover the full expenses of the further decoration works in the church. In 1481 and 1483 the churchwardens sold considerable amounts of grain, even bringing part of it on the market in Antwerp. ${ }^{166}$ This is all the more striking since the early 1480 s are known to have been years of deep crisis, caused by failed harvests that were as yet unseen. Even if Zoutleeuw briefly experienced a modest economic resurgence between 1466 and 1484, the harsh 
crisis that struck there was as unrelenting as it was elsewhere. This not only led to excessively high mortality rates - in Zoutleeuw too but also to an impressive increase in the price of grain. Apparently the churchwardens took advantage of this situation. ${ }^{167}$ By doing so, they were only just able to finance their expenses on interior decorations. If it is not immediately clear that the wardens promoted the devotion for financial benefit, we should consider other motivations, such as a quest for civic prestige or - most evidently - purely devotional grounds. The next chapter considers how the churchwardens responded to broader trends in the region and abroad. 